

\section{DISCLAIMER}

This report was prepared as an account of work sponsored by an agency of the United States Government. Neither the United States Government nor any agency Thereof, nor any of their employees, makes any warranty, express or implied, or assumes any legal liability or responsibility for the accuracy, completeness, or usefulness of any information, apparatus, product, or process disclosed, or represents that its use would not infringe privately owned rights. Reference herein to any specific commercial product, process, or service by trade name, trademark, manufacturer, or otherwise does not necessarily constitute or imply its endorsement, recommendation, or favoring by the United States Government or any agency thereof. The views and opinions of authors expressed herein do not necessarily state or reflect those of the United States Government or any agency thereof. 


\section{DISCLAIMER}

Portions of this document may be illegible in electronic image products. Images are produced from the best available original document. 


\section{Printed in the United States of America. Available from National Technical Information Service \\ U.S. Department of Commerce 5285 Port Royal Road, Springfield, Virginia 22161} NTIS price codes-Printed Copy: A03 Microfiche A01

This report was prepared as an account of work sponsored by an agency of the United States Government. Neither the United States Government nor any agency thereof, nor any of their employees, makes any warranty, express or implied, or assumes any legal liability or responsibility for the accuracy, completeness, or usefulness of any information, apparatus, product, or process disclosed, or represents that its use would not infringe privately owned rights. Reference herein to any specific commercial product, process, or service by trade name, trademark, manufacturer, or otherwise, does not necessarily constitute or imply its endorsement, recommendation, or favoring by the United States Government or any agency thereof. The views and opinions of authors expressed herein do not necessarily state or reflect those of the United States Government or any agency thereof. 
METALS AND CERAMICS DIVISION

\section{CORROSION OF A STAINLESS STEEL WASTE HEAT RECUPERATOR}

\section{J. I. Federer and V. J. Tennery}

Prepared for

Office of Industrial Programs Conservation and Solar Applications

Date Published: June 1980 .

NOTICE This document contains information of a preliminary nature. It is subject to revision or correction and therefore does not represent a final report

$$
\begin{gathered}
\text { OAK RIDGE NATIONAL LABORATORY } \\
\text { Oak Ridge, Tennessee } 37830 \\
\text { Operated hy } \\
\text { UNION CARBIDE CORPORATION } \\
\text { for the } \\
\text { DEPARTMENT OF ENERGY }
\end{gathered}
$$




\section{Acknowledgments}

The authors wish to acknowledge the contributions of others to the completion of this work: J.W. Geer, sample preparation; W. H. Warwick, optical microscopy; R. S. Crouse, electron microprobe analysis; and O. B. Cavin, x-ray diffraction. We thank T. G. Godfrey and J. C. Griess for their critical review and comments, and Technical Publications for preparing the report for publication. 


\section{Contents}

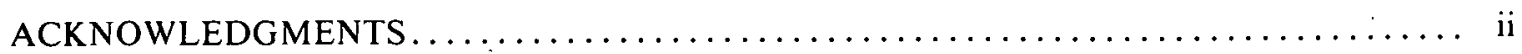

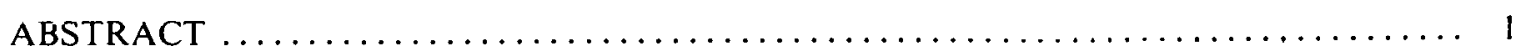

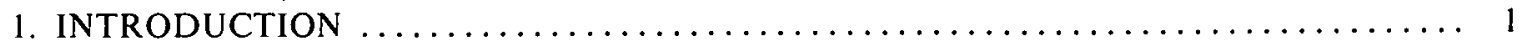

2. RECUPERATOR DESIGN AND MODE OF OPERATION $\ldots \ldots \ldots \ldots \ldots \ldots \ldots \ldots$

3. HISTORY OF. THE RECUPERATOR DEMONSTRATION $\ldots \ldots \ldots \ldots \ldots \ldots \ldots \ldots . \ldots$

4. VISUAL INSPECTION AND SAMPLING PLAN $\ldots \ldots \ldots \ldots \ldots \ldots \ldots \ldots \ldots \ldots \ldots$

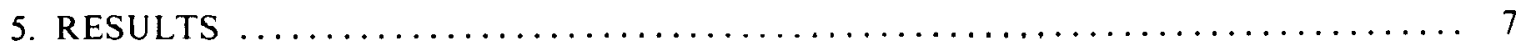

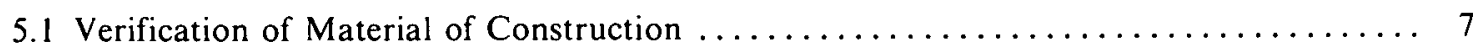

5.2 Identification of the Corrosion Product $\ldots \ldots \ldots \ldots \ldots \ldots \ldots \ldots \ldots \ldots \ldots \ldots \ldots \ldots \ldots \ldots \ldots$

5.3 Metallographic Examination and Electron Microprobe Analysis .............. 9

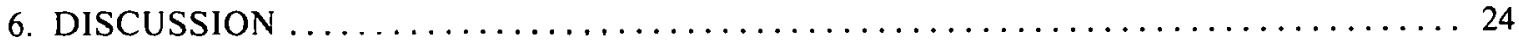

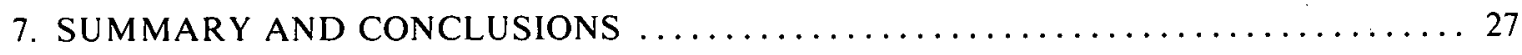

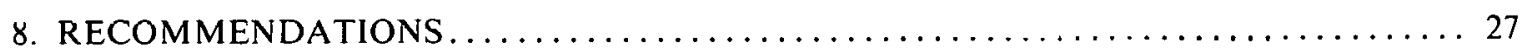

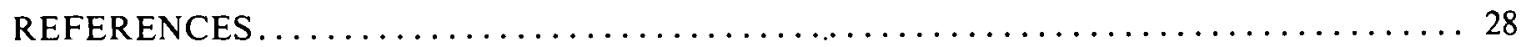

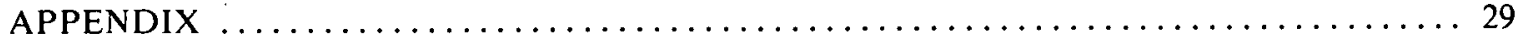




\title{
Corrosion of a Stainless Steel Waste Heat Recuperator
}

\author{
J. I. Federer V. J. Tennery
}

\begin{abstract}
Waste heat recuperation has significant potential for saving energy in fossil-fuel-fired industrial furnaces. Preheating the air used to burn the fuel can significantly reduce fuel consumption. The Office of Industrial Applications of the U.S. Department of Energy is contracting several high-temperature waste heat recuperation demonstrations with the objective of using successful efforts to stimulate the industrial utilization of these devices.

One of the recuperator demonstration contracts has as an objective the successful operation of a concentric-shell radiation recuperator of a new design on aluminum-scrap-remelting furnaces. The design employs type 309 stainless steel reradiant inserts within the type 309 stainless steel inner shell to increase heat radiation to the recuperator partition, thereby increasing the heat exhanger's effectiveness. The first demonstration recuperator in this program was installed on a furnace fired with No. 2 oil and melting ahnilt $60 \mathrm{Mg}$ (66 tons) of aluminum per 24-h day. The unit operated for about $30 \mathrm{~d}$ and provided air to the burner at $540^{\circ} \mathrm{C}$. During this period, a burner control misoperation provided very fuel-rich gases to the base of the recuperator. This fuel combined with safety dilution air at the recuperator base and burned within the recuperator. Also, during this period, air flow loss was detected at the burner. An inspection revealed that this was caused by failure of the partition wall separating the primary and secondary sides of the recuperator. Extensive corrosion of the partition wall and reradiant inserts was also observed. The recuperator was removed from the furnace for an analysis of the failure.

Sections along the recuperator partition were analyzed by using optical microscopy, electron microprobe, $x$-ray diffraction, and chemical analysis. Both the partition wall and the reradiant inserts had a thick surface scale and intergranular attack of the alloy beneath the scale. The corrosion was primarily sulfidation-oxidation caused by low oxygen and high sulfur in the flue gases and was possibly accelerated by cxcessively high temperatures. Extensive carbide precipitation occurred at grain boundarics and twin boundaries in grains beneath the surface scale. Chlorine and potassium were also detected in grain boundaries of the corroded alloy. The carbide precipitation and the presence of chlorides probably enhanced corrosion.
\end{abstract}

\section{INTRODUCTION}

An effective method of industrial energy conservation is recovery of some of the sensible heat from hot flue gases. Some industries have used this cost-effective conservation methnd for many years. Iron blast furnaces, for example, usually have sets of regenerators constructed of refractory bricks. Large glass-melting furnaces also utilize refractory-brick regenerators extensively. One or more regenerators preheat combustion air for the furnace while others are being heated by the furnace exhaust gases. In the present case, a stainless steel recuperator of the concentric-tube type, or radiation type, was installed by a DOE contractor on an aluminum-melting furnace to demonstrate its durability and obtain data needed for optimization of recuperator design and size. Two other demonstration recuperaturs, similar in design, will be installed on similar furnaces so that the operating characteristics of the three devices can be directly compared under similar conditions in actual plant operations.

The first recuperator, which is the subject of this report, operated for about $30 \mathrm{~d}$, supplying preheated $\left(\sim 540^{\circ} \mathrm{C}\right)$ combustion air to the furnace being fired with No. 2 oil. Erratic operating characteristics caused the recuperator to be shut down for inspection. Extensive corrosion and a break in the heat exchanger partition were observed, and the recuperator was removed from the 
furnace for further examination. This report describes the results of an analysis to determine the cause of the observed corrosion. The reasons for events that may have resulted in a particularly corrosive environment were not the subject of this analysis; however, knowledge of the corrosion mechanism may aid in reconstructing the sequence of events leading to the observed failure in the metal shell separating the secondary from the primary or flue side of the recuperator.

\section{RECUPERATOR DESIGN AND MODE OF OPERATION}

Figure 1 illustrates the recuperator attached to the exhaust flue of the aluminum-melting furnace. The effective height of the recuperator was $12.2 \mathrm{~m}(\sim 40 \mathrm{ft})$. The total height, including the adaptor section and dome top, was $14.2 \mathrm{~m}(\sim 47 \mathrm{ft})$. The basic recuperator consisted of two vertical, concentric tubes. The outer tube was $1.17 \mathrm{~m} \mathrm{(} \sim 46 \mathrm{in}$.) in inside diameter with a 6.35 -mm-thick

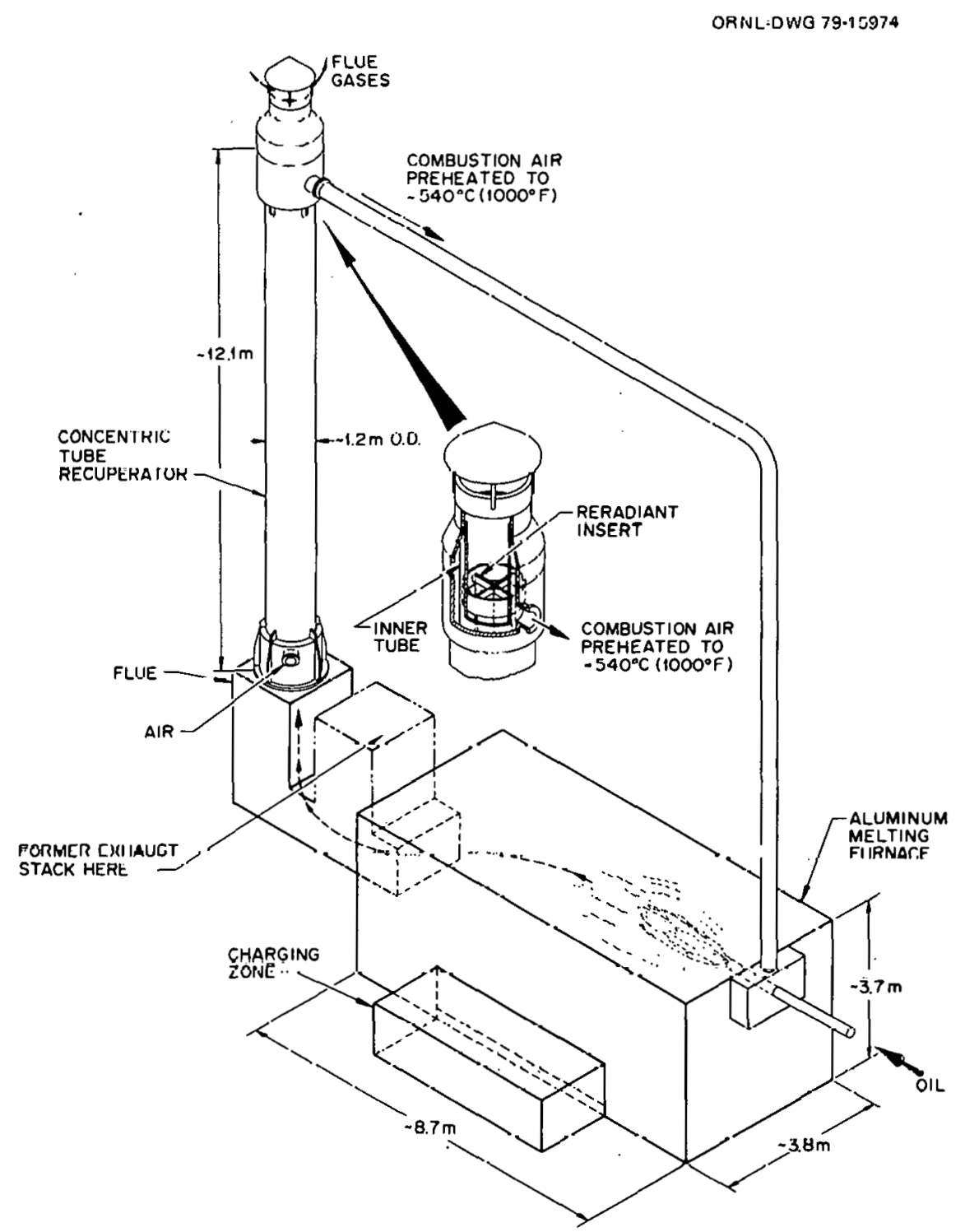

Fig. 1. Stainless steel recuperator on an aluminum-melting furnace. 
$(0.25$-in.) wall. The inner wall of the outer tube was lined with a 76-mm-thick $(\sim 3$-in.) layer of refractory insulation. The inner tube, or partition wall, was $0.97 \mathrm{~m}(\sim 38 \mathrm{in}$.$) in inside diameter with$ a 6.35 -mm-thick $(0.25$-in.) wall. The annulus between the partition wall and the refractory-lined outer tube was $25 \mathrm{~mm}(1 \mathrm{in}$.$) .$

Four reradiant inserts were positioned inside the partition wall as shown in Fig. 1. Each insert was $11.7 \mathrm{~m}(\sim 38 \mathrm{ft})$ high $\times 0.45 \mathrm{~m}(17.5 \mathrm{in}$.) wide $\times 5 \mathrm{~mm}(0.1875$ in.) thick. The inserts extended almost the effective length of the recuperator. The four inserts were arranged in a cross pattern with $90^{\circ}$ included angles. During operation the inserts radiate heat to the inner wall, thereby increasing heat transfer from the hot flue gases. The partition wall and the reradiant inserts were constructed of type 309 stainless steel. The inserts were held in a $90^{\circ}$ cross by Incoloy $800 \mathrm{H}$ angle brackets bolted to the inserts.

The aluminum-melting furnace was heated by an oil burner using No. 2 fuel oil. The combustion products of the oil flame and any process carry-over passed through the flue to the inner wall of the recuperator, which served as a stack. The inner side of the partition wall and the reradiant inserts were constantly exposed to the flue gases. Combustion air for the oil burner was preheated by passage through the annulus between the partition wall and the refractory-lined outer tube. Ambient air entered the annulus at the bottom of the recuperator, as shown in Fig. 1, exited at the top, then passed through a duct to the combustion chamber of the oil burner. The heat recovered from the flue gases in this manner decreased the amount of fuel oil required to attain the necessary furnace temperature of $\sim 760^{\circ} \mathrm{C}\left(\sim 1400^{\circ} \mathrm{F}\right)$.

\section{HISTORY OF THE RECUPERATOR DEMONSTRATION}

The furnace to which the recuperator was attached was used to melt a charge consisting of reclaimed beverage cans, oil-contaminated stamping scrap, and other scrap on a continual basis, using three shifts per day. The production rate was 18.1 to $20.4 \mathrm{Mg}$ per 8 -h shift $(40,000$ to 45,000 lb). Scrap was loaded into the furnace in the charging zone, and a salt mixture weighing about $10 \%$ of the scrap. weight was charged with the metal. The composition of the salt mixture was $50 \%$ $\mathrm{NaCl}-45 \% \mathrm{KCl}-5 \% \mathrm{Na}_{3} \mathrm{AlF}_{6}$ by weight. Since the charging zone was separated from the bulk of the molten aluminum by a furnace bridge wall, the salt mixture was theoretically confined to the charging zone.

The recuperator operated in a stable condition for about $30 \mathrm{~d}$. During this period the combustion air temperature measured at the exit port of the recuperator was $\sim 540^{\circ} \mathrm{C}\left(\sim 1000^{\circ} \mathrm{F}\right)$. A thermocouple in the roof of the furnace measured the furnace temperature, and the signal from this thermocouple actuated a controller which adjusted a combustion air valve. The oil flow valve was, in turn, adjusted by a fuel/air ratio controller so that the fuel mixture always contained more than the stoichiometric amount of air for complete combustion of the fuel. An examination of recorded data and the reconstruction of events allowed the DOE contractors to deduce the cause of the failure. After a period of prolonged heating necessiated by charging of metal to be melted, the furnace thermocouple reached the normal set-point temperature. Upon receiving this signal from the thermocouple, the controller adjusted the combustion air valve to decrease the flow of air. The oil flow, however, did not decreasc as usual because of a mechanical failure. This allowed the oil flow to remain at a maximum rate when the combustion air, on command from the controller, had decreased. As a result, unburned fuel passed through the flue into the recuperator. A dilution air blower, turned on by high temperatures in the flue, forced extra air into the flue beneath the recuperator. The unburned fuel burned with this air in the recuperator, and the excessive temperature caused a split to 
develop in the partition wall. Subsequently, when additional metal charging caused the furnace themocouple to call for heat, the furnace operators observed that an insufficient amount of combustion air was being delivered to the oil burner. The operators manually controlled the furnace for the next few days as the air flow continued to decrease. While observing the flame, the operators attempted to manually adjust the oil flow to maintain a stoichiometric or slightly air-rich fuel mixture.

During the period of manual furnace control, a bypass pipe was installed to allow the recuperator to be isolated while the furnace remained in operation. Simultaneously, the problem in the recuperator was being diagnosed with the aid of pressure taps at several locations in the annulus and by an analysis of the flue gases. The data indicated that a break had occurred in the recuperator partition wall between the flue gas and the combustion air. This break allowed combustion air to enter the flue gases due to the pressure differential (and be lost) rather than flow to the combustion chamber as intended. As a resuult, the oil burnér operăted with lessis than the normal amount of air. During the period just before the problem became known and during the diagnostic period, the burner may have operated with insufficient air to maintain oxidizing conditions in the flue gases, either because the oil valve had failed or because the operators could not maintain the normal fuel/air ratio while manually controlling furnace temperatures. An analysis of the flue gases in the recuperator during the diagnostic period (dilution air off) revealed the following:

\begin{tabular}{|c|c|c|}
\hline & \multicolumn{2}{|c|}{ Approximate location } \\
\hline & Top & Bottom \\
\hline Oxygen. $\%$ & $11-15$ & 0.8 \\
\hline Combustibles, & 0 & 0.5 \\
\hline
\end{tabular}

These data supported other indications that a brcak had occurred in the partition wall of the recuperator, since oxygen was being introduced into the flue gases somewhere above the bottom of the recuperator. During the period of failure, manual control, and diagnosis, the oxygen content of the flue gases may have fluctuated considerably. The stainless steel recuperator partition may have been alternately exposed to oxidizing and nonoxidizing conditions, since the operators used the appearance of the flame in the furnace in attempts to maintain a near stochiometric air/ fuel mixture.

\section{VISUAL INSPECTION AND SAMPLING PLAN}

Figure 2 is a view looking up into the recuperator still attached to the furnace. Severe corrosion was evidenced by a thick corrosion product on all surfaces and by loss of material from the reradiant inserts. At this location the inserts had partially collapsed from the $90^{\circ}$ cross arrangement due to corrosion of the inserts and of the angle brackets bolting them together. Figure 3 is another view looking into the bottom of the recuperator after the recuperator was removed from the furnace and placed in a horizontal position. The reradiant inserts collapsed completely during removian and handling. Corrosion products on the inner wall, loss of material from the inserts, and inward buckling of the partition wall are shown in Fig. 3. Buckling apparently resulted in a hole in the partition wall, as shown in Fig. 4. Figure 5 shows that the dome and inserts at the top of the recuperator were also corroded. The principal observations made during this inspection were:

- Distortion (buckling) of the partition wall occurred at several locations $\sim 3.7$ to $\sim 6.1 \mathrm{~m}(\sim 12$ to $\sim 20 \mathrm{ft}$ ) from the bottom. 
Y 163944

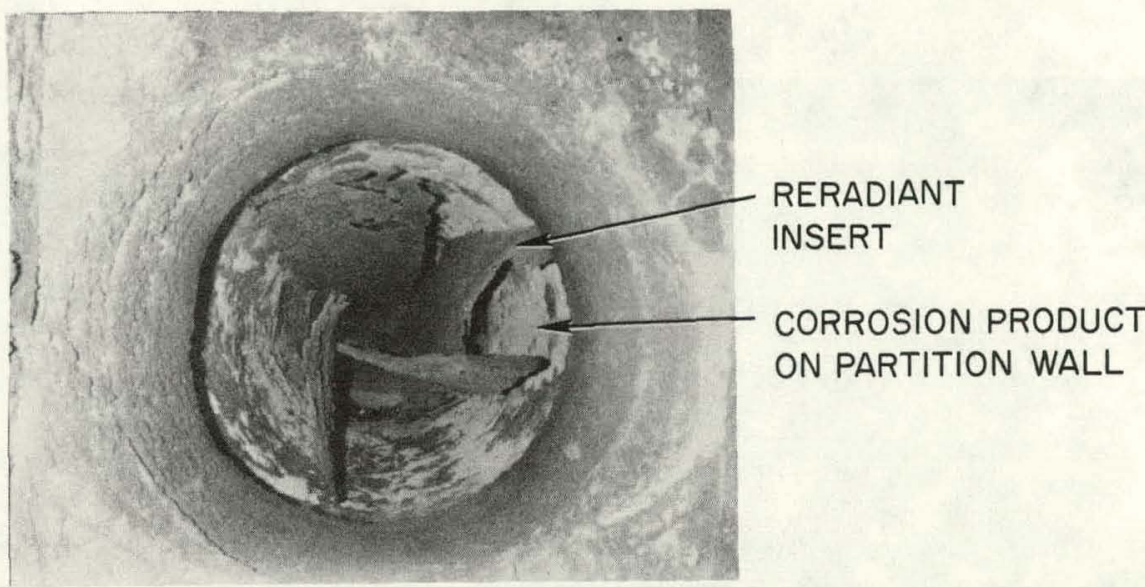

Fig. 2. View of partition wall and reradiant inserts at bottom of recuperator. The recuperator was still in place on the furnace flue.

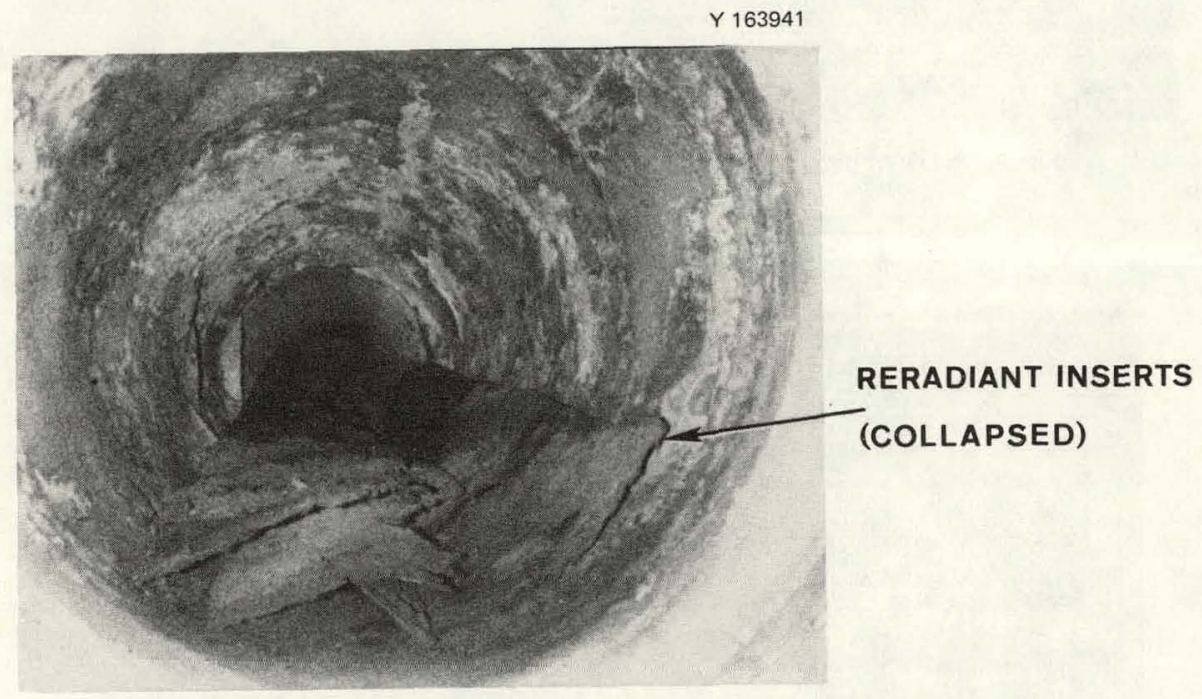

Fig. 3. View from bottom of recuperator after removal from furnace.

- An irregular-shaped hole occurred in a distorted area $\sim 4.9 \mathrm{~m}(\sim 16 \mathrm{ft})$ from the bottom.

- Thick corrosion products occurring on the wall and reradiant inserts were light gray above the hole and dark gray below the hole.

- Severe corrosion occurred on the reradiant inserts at the bottom end, with substantial loss of material.

- The Incoloy $800 \mathrm{H}$ angle brackets on the reradiant inserts were severely corroded; in fact, some were completely disintegrated.

- Discoloration on the outer wall approximately adjacent to the hole in the partition wall indicated that excessive temperatures occurred at that location. 
Y 170659

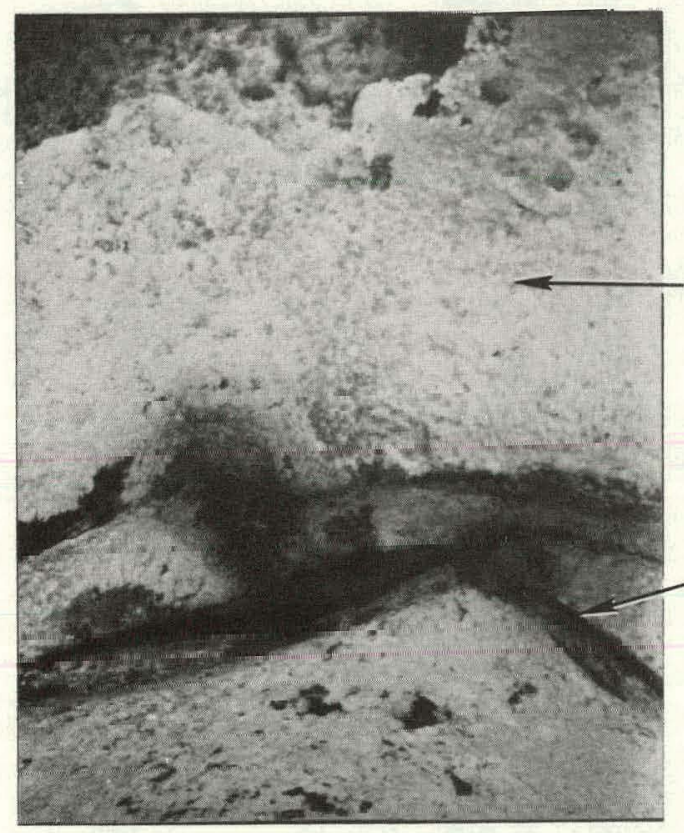

CORROSION

PRODUCT

BREAK IN PARTITION

WALI

Fig. 4. Break in partition wall about $4.9 \mathrm{~m}$ from bottom of recuperator.

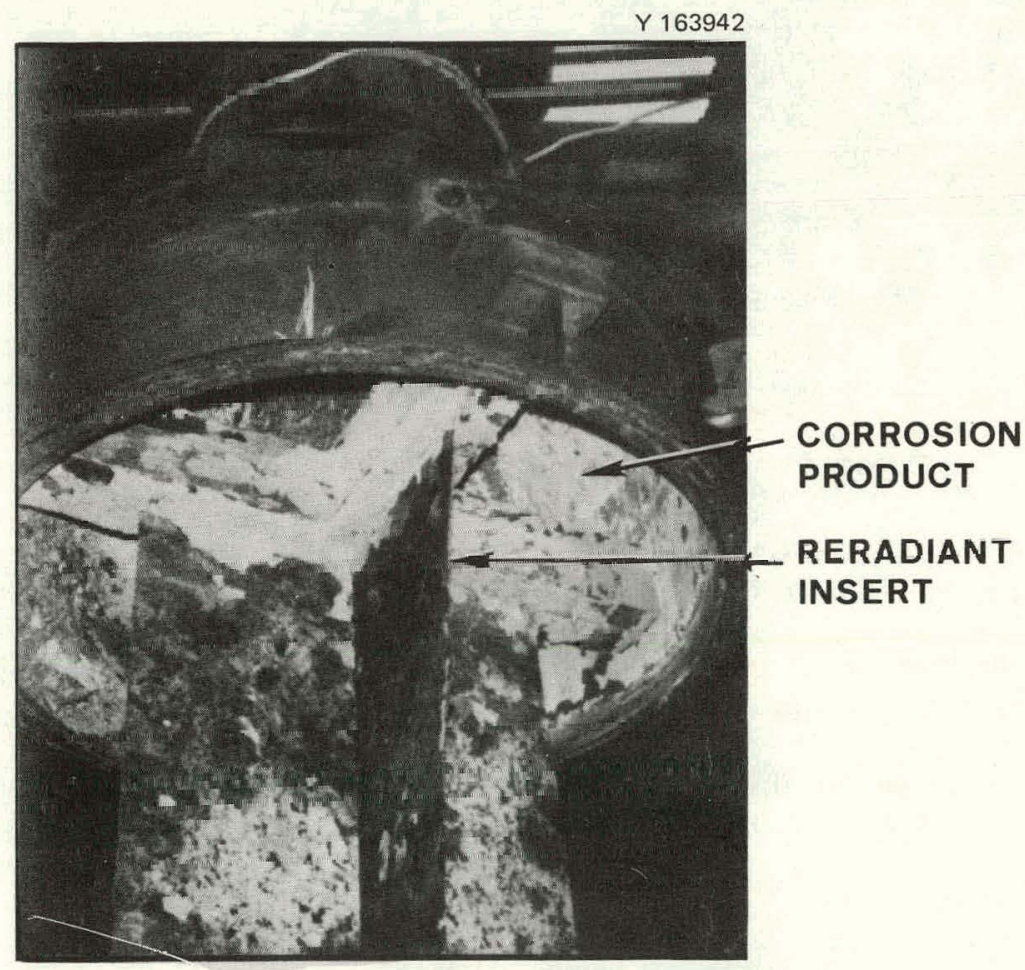

Fig. 5. Dome and reradiant inserts at top of recuperator. 
- A quantity of corrosion products had collected in the flue below the recuperator; this material, which contained layers of different colors, apparently fell from the recuperator during the period of failure, manual control, and diagnosis.

Samples were taken for chemical and microscopic analyses at the locations shown in Table 1. The corrosion product, identified as samples RD-1, -2, -3, -4, and -5 , was easily lifted from the surface. A piece of refractory castable (sample C-1) was removed from the insulating ring at the bottom of the recuperator. This refractory material contained cracks but appeared to be still functional. The corroded metal samples (RI-3, RW-3, etc.) of the reradiant inserts and the partition wall were first cut with an oxyacetylene torch. These samples were at least 0.3 by $0.3 \mathrm{~m}(\sim 12$ by $\sim 12$ in.). Smaller samples measuring $\sim 80$ by $80 \mathrm{~mm}$ were cut from the larger samples, using a band saw. These smaller samples were taken from areas unaffected by cutting with the oxyacetylene torch. Finally, even smaller samples were cut with an abrasive cutoff wheel. Water was the only coolant used while the samples were cut.

Table 1. Location of sample for analyses

\begin{tabular}{llcl}
\hline Sample material & Designation & $\begin{array}{c}\text { Distance from } \\
\text { bottom }(\mathrm{m})\end{array}$ & Sample location \\
\hline Corrosion product & RD-1 & 13.6 & Damper near dome \\
& RD-2 & 11.6 & Wall \\
& RD-3 & 7.3 & Reradiant insert \\
& RD-4 & 3.0 & Wall \\
& RD-5 & 1.8 & Reradiant insert \\
Refractory & C-1 & 0.3 & \\
Corroded metal & RI-3A & 0.9 & Reradiant insert \\
& RI-3B & 0.9 & Reradiant insert \\
& RW-3 & 0.9 & Wall \\
& RI-16 & 4.9 & Reradiant insert \\
& RW-16 & 4.9 & Wall \\
& RI-24 & 7.3 & Reradiant insert \\
& RW-24 & 7.3 & Wall \\
& RI-35 & 10.7 & Reradiant insert \\
& RW-35 & 10.7 & Wall \\
\hline
\end{tabular}

\section{RESULTS}

\subsection{Verification of Material of Construction}

The extensive corrosion observed in the recuperator prompted a chemical analysis of the partition wall and reradiant inserts to confirm that these components were constructed of type 309 stainless steel as intended. The corrosion product was machined from the partition wall and the reradiant insert samples before the metal samples were analyzed. The results of chemical analyses are shown in Table 2. The typical composition of a type 309 stainless steel archive sample is included for comparison. The results show that the archive material, partition wall, and reradiant insert were actually type 309 stainless steel.

\subsection{Identification of the Corrosion Product}

Samples of the corrosion product from the partition wall and reradiant inserts and of the refractory castable were crushed to pass a 100 -mesh screen $(150 \mu \mathrm{m})$, dried at $125^{\circ} \mathrm{C}$ for $16 \mathrm{~h}$, then 
Table 2. Chemical analyses of stainless steel samples

\begin{tabular}{llccc}
\hline \multirow{2}{*}{ Element } & \multicolumn{4}{c}{ Composition (\%) } \\
\cline { 2 - 5 } & $\begin{array}{c}\text { Typical } \\
\text { type 309 }\end{array}$ & Archive & RW-35 & RI-35 \\
\hline $\mathrm{C}$ & 0.20 max & 0.073 & 0.068 & 0.052 \\
$\mathrm{Co}$ & & 0.2 & 0.2 & 0.2 \\
$\mathrm{Cr}$ & $22-24$ & 24 & 23 & 23 \\
& & $22.90^{a}$ & $22.79^{a}$ & $23.18^{a}$ \\
$\mathrm{Cu}$ & & 0.3 & 0.3 & 0.3 \\
$\mathrm{Fe}$ & Major & Major & Major & Major \\
$\mathrm{Mn}$ & 2.0 max & 1.9 & 1.7 & 1.8 \\
$\mathrm{Mo}$ & & 0.4 & 0.3 & 0.2 \\
$\mathrm{Nb}$ & & $<0.05$ & $<0.05$ & $<0.05$ \\
$\mathrm{Ni}$ & $12-15$ & 14 & 15 & 15 \\
& & $14.05^{a}$ & $13.99^{a}$ & $14.57^{a}$ \\
$\mathrm{P}$ & 0.045 max & 0.035 & 0.034 & 0.031 \\
$\mathrm{~S}$ & 0.030 max & 0.004 & 0.004 & 0.014 \\
$\mathrm{Si}$ & 1.0 inax & 117 & 0.6 & 0.7 \\
$\mathrm{Ta}$ & & $<0.05$ & $<0.05$ & $<0.05$ \\
$\mathrm{Ti}$ & & $<0.02$ & $<0.02$ & $<0.02$ \\
$\mathrm{~V}$ & & 0.05 & 0.05 & 0.05 \\
& & & &
\end{tabular}

analyzed spectrographically. The results shown in Table 3 are accurate to within one-half to two times the reported value. In addition to the elements originally present in the steel, the five samples of corrosion product contained significant amounts of $\mathrm{Cl}, \mathrm{K}, \mathrm{Na}$, and $\mathrm{S}$. The refractory castable also contained high concentrations of these elements, although $\mathrm{K}$ and $\mathrm{Na}$ may have been present in the original material. The source of $\mathrm{Cl}, \mathrm{K}$. and Na was probably the salt mixture added to the scrap metal in the charging zone of the furnace. The salt apparently was carried under the bridge wall, which separated the charging $70 n$ from the bulk of the molten aluminum, possibly as a result of mechanical manipulation of the scrap by the furnace operators. A common practice is to push the scrap beneath the surface of the molten metal, using long poles. Scrap and salt together may have been pushed beneath the hridge wall during this operation. Afterward, the salt may have been carried into the recuperator as entrained solids or as vapor in the flue gases. The main source of the sulfur was undoubtedly the No. 2 fuel oil used to fire the furnace, since this oil contained $0.5 \% \mathrm{~S}$ and $0.001 \%$ ash. Oil residues on some of the scrap may have contributed sulfur also.

$\Lambda \mathrm{n} x$-ray diffraction analysis of the powdered corrosion product was performed for the purposc of identifying crystalline phases. The diffraction patterns contained many diffuse peaks, which suggest either very small crystallite size or poorly crystallized material. The measured lattice spacings of the samples were compared with the lattice spacings of various iron, chromium, and nickel oxides and with various binary and ternary oxides of iron, chromium, and nickel in an effort to identify the phases present. The results of this analysis are shown in Table 4, and details of the analysis are presented in the Appendix. Only four phases- $\mathrm{Fe}_{2} \mathrm{O}_{3}, \mathrm{Fe}_{3} \mathrm{O}_{4}, \mathrm{Cr}_{2} \mathrm{O}_{3}$, and $\mathrm{Cr}_{3} \mathrm{O}_{4}$-were definitely identifed in the samples. The Appendix shows unidentified lattice spacings for each sample, which indicates that other phases were present. The lattice spacings of various iron, chromium, and nickel sulfates and sulfides were compared with the data, but no satisfactory correlations were found. The corrosion product may consist of a complex mixture of metal oxides, sulfates, and sulfides. 
Table 3. Spectrographic analyses (ppm) of samples from partition wall and reradiant inserts

\begin{tabular}{|c|c|c|c|c|c|c|}
\hline \multirow{2}{*}{ Element } & \multicolumn{5}{|c|}{ Corrosion product } & \multirow{2}{*}{$\begin{array}{c}\text { Refractory } \\
\text { C-1 }\end{array}$} \\
\hline & RD-1 & RD-2 & RD-3 & RD -4 & RD-5 & \\
\hline $\mathrm{Al}$ & 50 & 50 & 50 & 10 & 10 & Major \\
\hline As & 3 & 1 & 3 & 1 & 3 & 30 \\
\hline B & 5 & 5 & 2 & 2 & 3 & 5 \\
\hline $\mathrm{Ba}$ & 10 & 3 & 1 & 3 & 3 & 100 \\
\hline $\mathrm{Ca}$ & 200 & 70 & 30 & 50 & 20 & Major \\
\hline $\mathrm{Cl}$ & $>1000$ & 600 & 400 & $>1000$ & $>1000$ & $>1000$ \\
\hline Co & 10 & 10 & 30 & 30 & 30 & 30 \\
\hline $\mathrm{Cr}$ & Major & Major & Major & Major & Major & 300 \\
\hline $\mathrm{Cu}$ & 50 & 50 & 150 & 150 & 50 & 50 \\
\hline $\mathrm{Eu}$ & 50 & 10 & 10 & 10 & 10 & 10 \\
\hline $\mathrm{F}$ & $<1$ & $<1$ & $<1$ & $<1$ & $<1$ & $<1$ \\
\hline $\mathrm{Fe}$ & Major & Major & Major & Major & Major & Major \\
\hline K & Major & Major & Major & Major & Major & Major \\
\hline $\mathrm{Mg}$ & 10 & 10 & 10 & 10 & 10 & 30 \\
\hline $\mathrm{Mn}$ & 700 & 400 & 200 & 200 & 200 & 200 \\
\hline Mo & 5 & 20 & 100 & 50 & 100 & 20 \\
\hline $\mathrm{Na}$ & Major & Major & Major & Major & Major & Major \\
\hline $\mathrm{Nb}$ & $<0.5$ & 1 & 20 & 1 & 1 & 5 \\
\hline $\mathrm{Ni}$ & 1000 & 1000 & $>1000$ & $>1000$ & $>1000$ & 100 \\
\hline $\mathrm{P}$ & 5 & 5 & 20 & 20 & 20 & 50 \\
\hline $\mathrm{Pb}$ & 300 & 50 & 5 & $<2$ & 100 & 200 \\
\hline $\mathrm{Rb}$ & 20 & 20 & 10 & 20 & 5 & 20 \\
\hline S & Major & Major & Major & Major & Major & Major \\
\hline $\mathrm{Si}$ & 500 & 500 & 500 & 200 & $>1000$ & Major \\
\hline $\mathrm{Sn}$ & 50 & 5 & 3 & 5 & 20 & 5 \\
\hline $\mathrm{Sr}$ & $<0.5$ & $<0.5$ & 0.5 & 1 & 0.5 & 50 \\
\hline Ta & 100 & 100 & 3 & 30 & 100 & $<1$ \\
\hline $\mathrm{Ti}$ & 10 & 10 & 300 & 20 & 70 & $>1000$ \\
\hline $\mathrm{U}$ & 1 & 1 & $<1$ & $<1$ & $<1$ & 3 \\
\hline V & 5 & 10 & 100 & 20 & 20 & 200 \\
\hline $\mathrm{Zn}$ & 100 & 100 & 30 & 100 & 30 & 30 \\
\hline $\mathrm{Zr}$ & $<1$ & $<1$ & $<1$ & $<1$ & $<1$ & 30 \\
\hline
\end{tabular}

Table 4. Summary of crystalline phases identified in corrosion product

\begin{tabular}{cl}
\hline $\begin{array}{c}\text { Corrosion product } \\
\text { sample }\end{array}$ & \multicolumn{1}{c}{ Crystalline phases identified } \\
\hline RD-1 & $\mathrm{Fe}_{2} \mathrm{O}_{3}, \mathrm{Cr}_{3} \mathrm{O}_{4}, \mathrm{Cr}_{2} \mathrm{O}_{3}$ (possible) \\
RD-2 & $\mathrm{Fe}_{2} \mathrm{O}_{3}, \mathrm{Fe}_{3} \mathrm{O}_{4}, \mathrm{Cr}_{3} \mathrm{O}_{4}, \mathrm{Cr}_{2} \mathrm{O}_{3}$ \\
RD-3 & $\mathrm{Fe}_{2} \mathrm{O}_{3}, \mathrm{Fe}_{3} \mathrm{O}_{4}, \mathrm{Cr}_{3} \mathrm{O}_{4}, \mathrm{Cr}_{2} \mathrm{O}_{3}$ \\
RD-4 & $\mathrm{Fe}_{2} \mathrm{O}_{3}, \mathrm{Fe}_{3} \mathrm{O}_{4}$ (possible), $\mathrm{Cr}_{3} \mathrm{O}_{4}, \mathrm{Cr}_{2} \mathrm{O}_{3}$ \\
RD-5 & $\mathrm{Fe}_{2} \mathrm{O}_{3}, \mathrm{Fe}_{3} \mathrm{O}_{4}$ (possible), $\mathrm{Cr}_{3} \mathrm{O}_{4}, \mathrm{Cr}_{2} \mathrm{O}_{3}$ \\
\hline
\end{tabular}

\subsection{Metallographic Examination and Electron Microprobe Analysis}

The microstructure of the type 309 slaiulcss stecl used in construstion of the recuperator is shown in Fig. 6. During prior fabrication into sheet, the nonmetallic inclusions typically contained in this steel enlongated into thin sheets. These inclusions, which are apparent as dark horizontal lines in Fig. 6, do not significantly affect the mechanical properties or corrosion behavior of the steel. The 


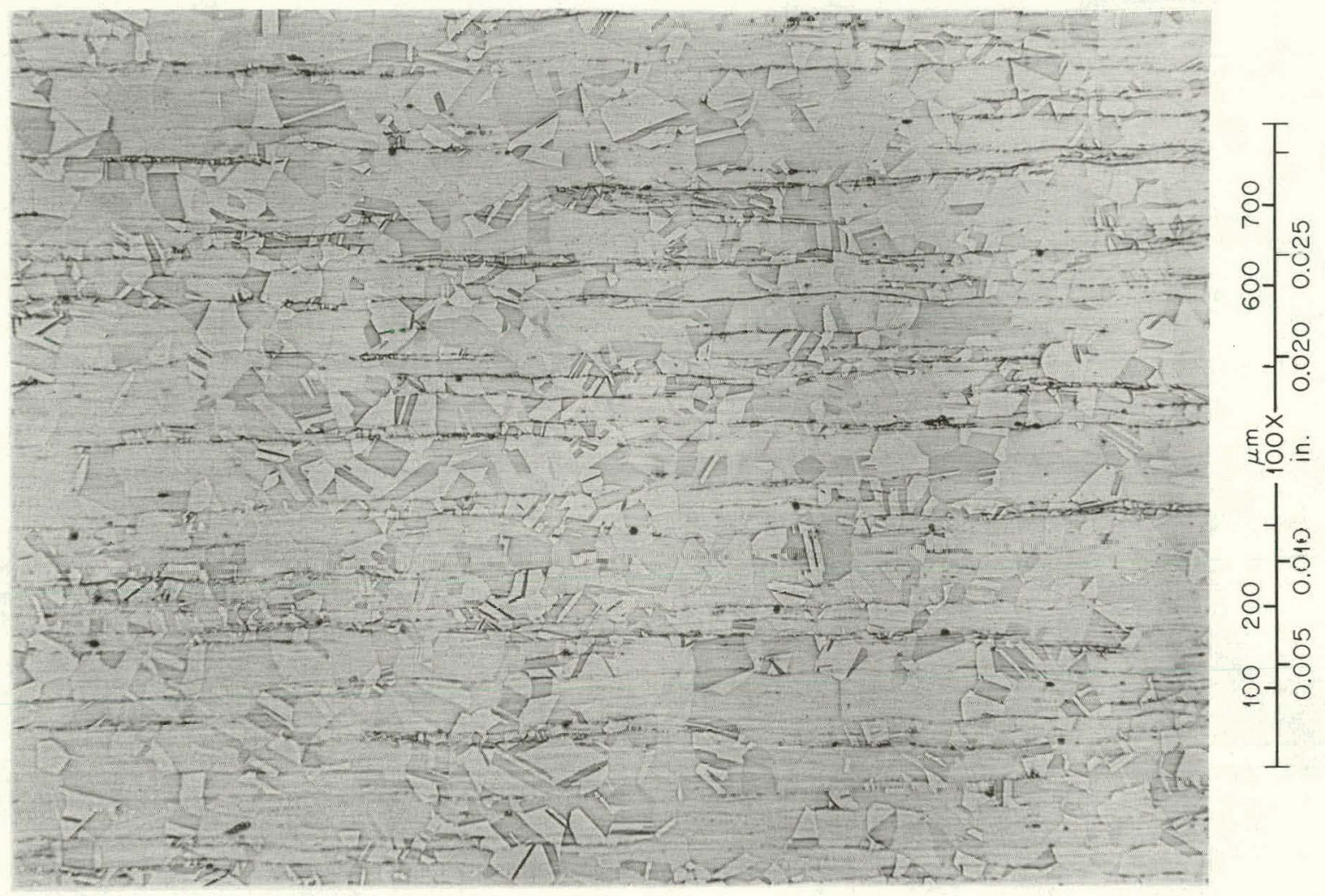

Fig. 6. Microstructure of type 309 stainless steel used in fabrication of recuperator.

steel was probably recrystallized during fabrication, but the angular grain structure suggests that further fabrication occurred below the recystallization temperature.

Samples of the reradiant insert were mounted and polished so that the corrosion product and base metal could he examined in a plane perpendicula to the surface. Figure 7 shows polished (unetched) sections of the corrosion product and base metal of the reradiant inserts at intervals along the height of the recuperator. The corrosion product, or surface scale, appears to be a nonhomogeneous mixture of compounds and porosity. Cracks in the scale were probably caused by temperature variations coupled with differences in thermal expansion between the scale and alloy, and these cracks eventually caused spalling of the scale. The scale had apparently spalled from sample RI-3A because the scale plus the base metal were only $\sim 0.9 \mathrm{~mm}$ thick at this location $(\sim 0.9$ $\mathrm{m}$ from the bottom of the recuperator). Since the reradiant insert was $\sim 5 \mathrm{~mm}(3 / 16 \mathrm{in}$.) thick, corrosion had consumed $>80 \%$ of the original thickness.

The main teature of the base metal, as shown in Fig. 7, is the extensive intergranular attack below the surface scale. The attack is clearly visible even though the samples are not etched. Intergranular corrosion appears to completely isolate grains, resulting in gradual disintegration of the base metal. The grain boundaries of sample RI-3B contained a precipitate which is clearly visible in Fig. 7. The nature of this precipitate and other characteristics of the corrosion product and base metal will be discussed.

The miscrostructure of the partition wall at intervals along the height of the recuperator is shown in Fig. 8. The appearance of these samples is similar to that of the inserts, being characterized by a surface scale and intergranular corrosion of the base metal below the scale. Figures 7 and 8 

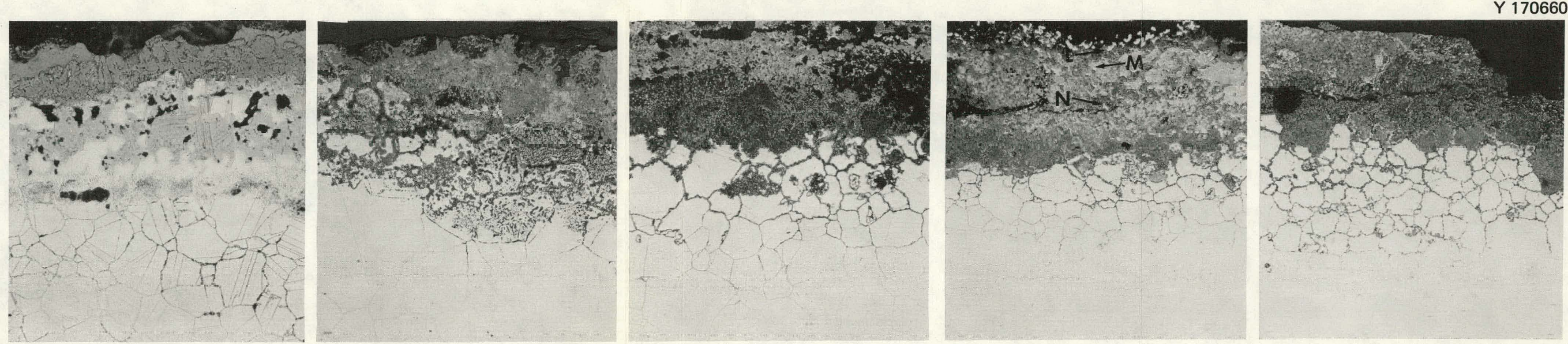

$$
1 0 \longdiv { \mathrm { mm } }
$$
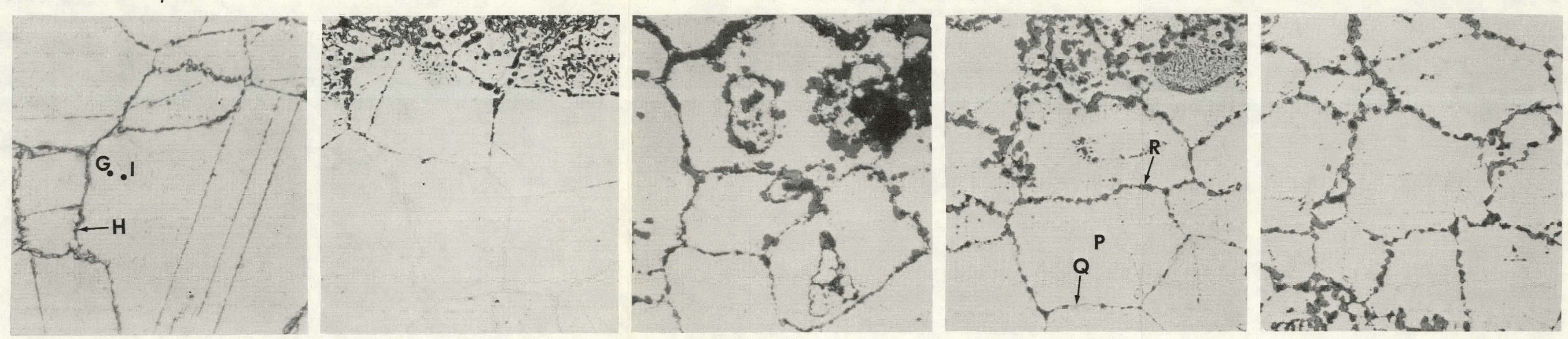

SAMPLE NUMBER RI-3A DISTANCE FROM

BOTTOM (m)

0.9

RI-3B

0.9
RI-16

4.9
RI-24

7.3
$\mathrm{RI}-35$

10.7

Fig. 7. Polished sections of reradiant insert at intervals showing corrosion product and intergranular attack of alloy. 

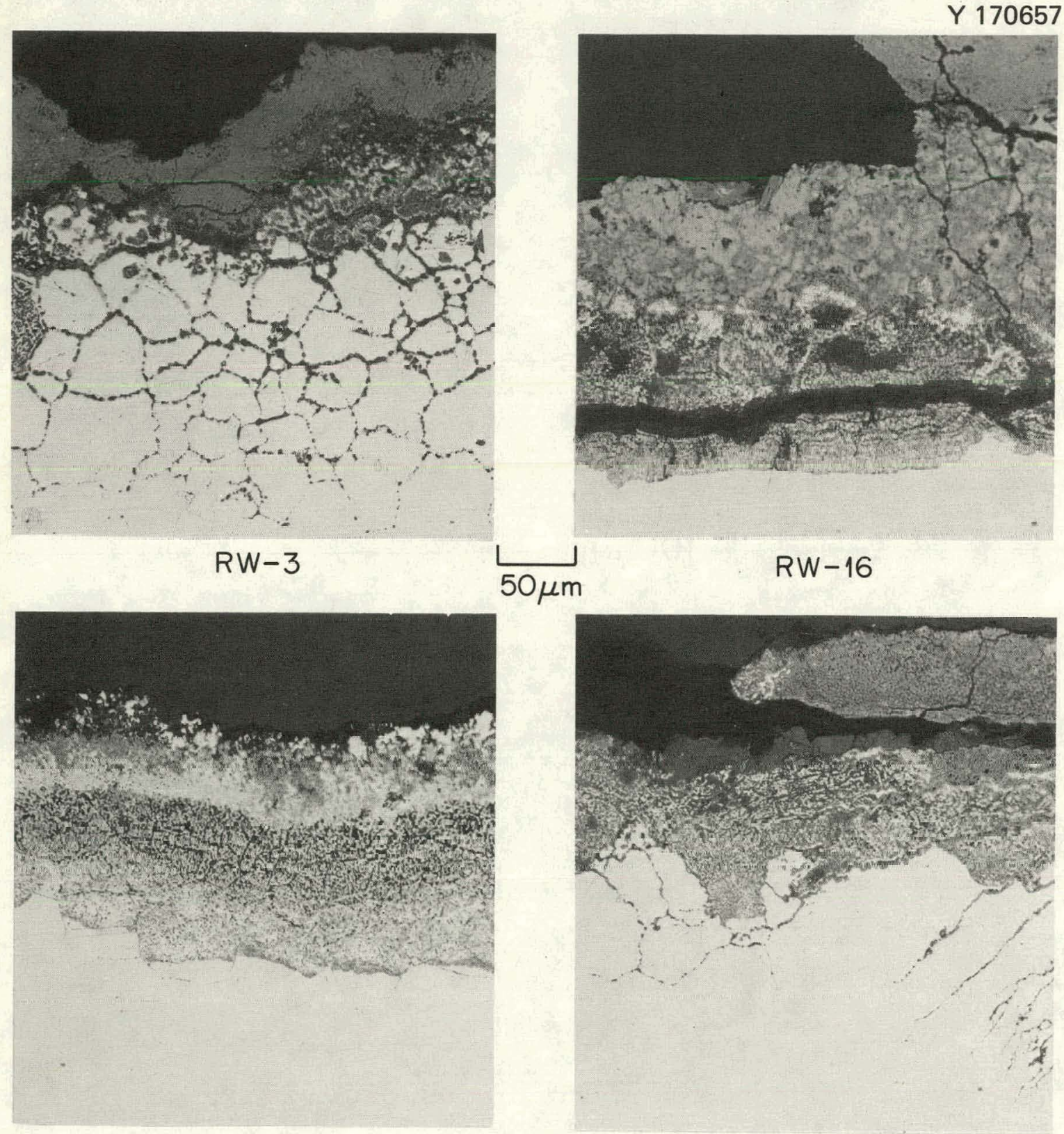

$\mathrm{RW}-24$

RW-35

Fig. 8. Polished sections of partition wall at intervals, showing corrosion product and intergranular attack of alloy. Distance from bottom of recuperator: RW-3, $0.9 \mathrm{~m}$; RW-16, 4.9 m; RW-24, 7.3 m; RW-35, $10.7 \mathrm{~m}$.

clearly show that corrosion occurred over the entire height of the recuperator and that the same corrosion process was operating at all locations.

The distribution of elements in the corrosion product and the base metal was determined with an electron microprobe. The corrosion product on sample RI-3A, which was $\sim 0.9 \mathrm{~m}$ from the bottom of the recuperator, is shown in Fig. 9. Characteristic x-ray spectra for regions $A$ to $F$ in Fig. 9 are shown in Figs. 10 to 15 . The relative peak heights in Figs. 10 to 15 indicate the relative 


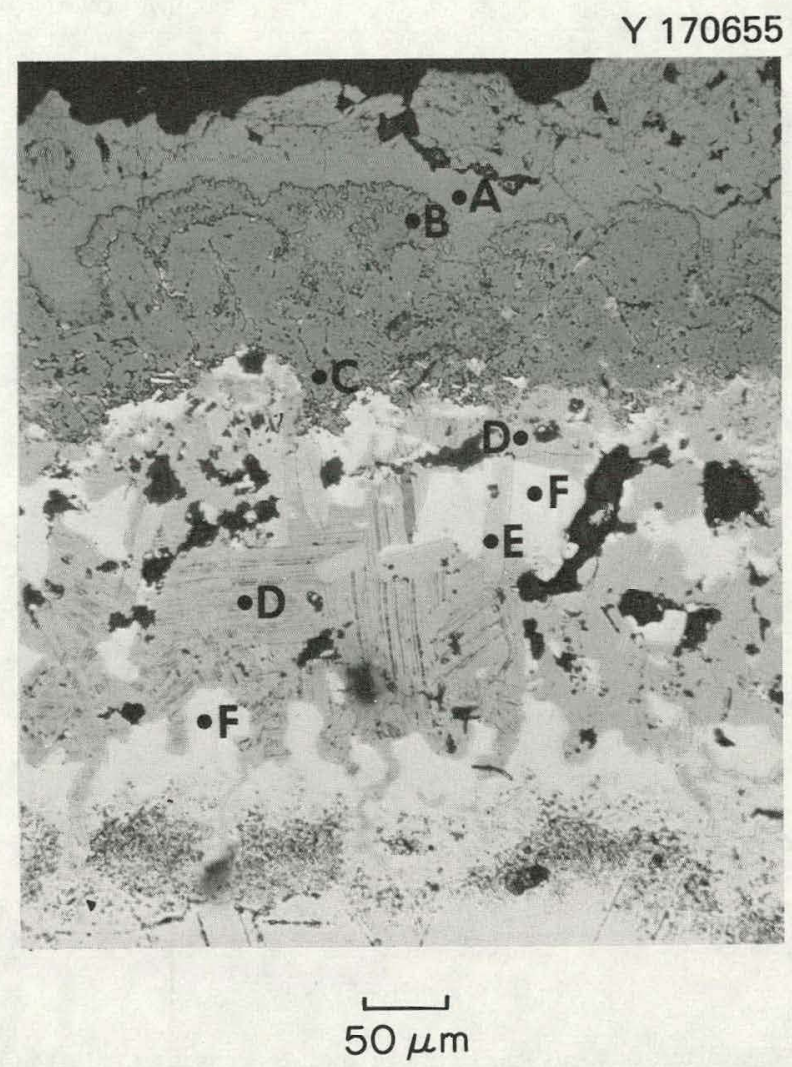

Fig. 9. Corrosion product on sample RI-3A located $\sim 0.9 \mathrm{~m}$ from bottom of recuperator.

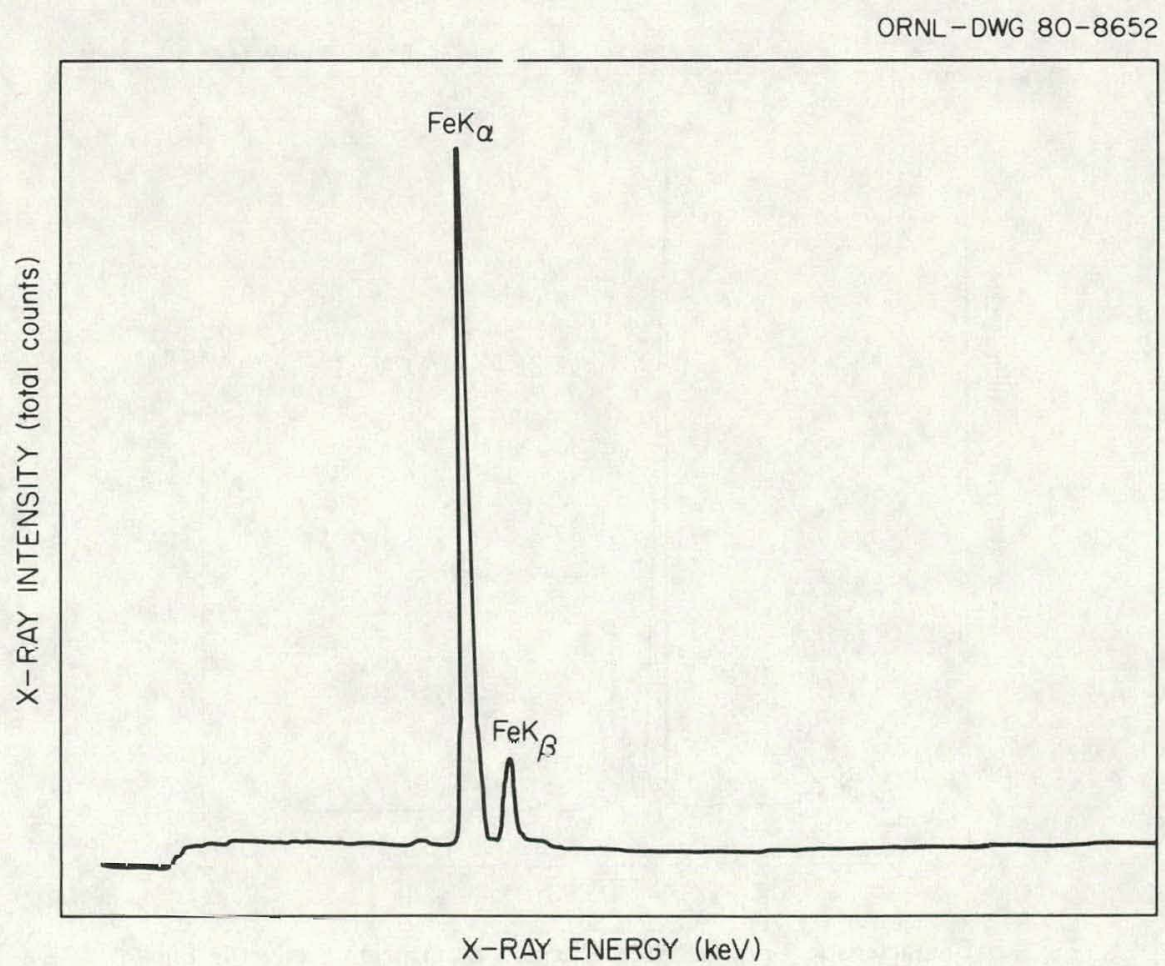

Fig. 10. Characteristic x-ray spectrum of region 4 corrosion product in Fig. 9. 
14

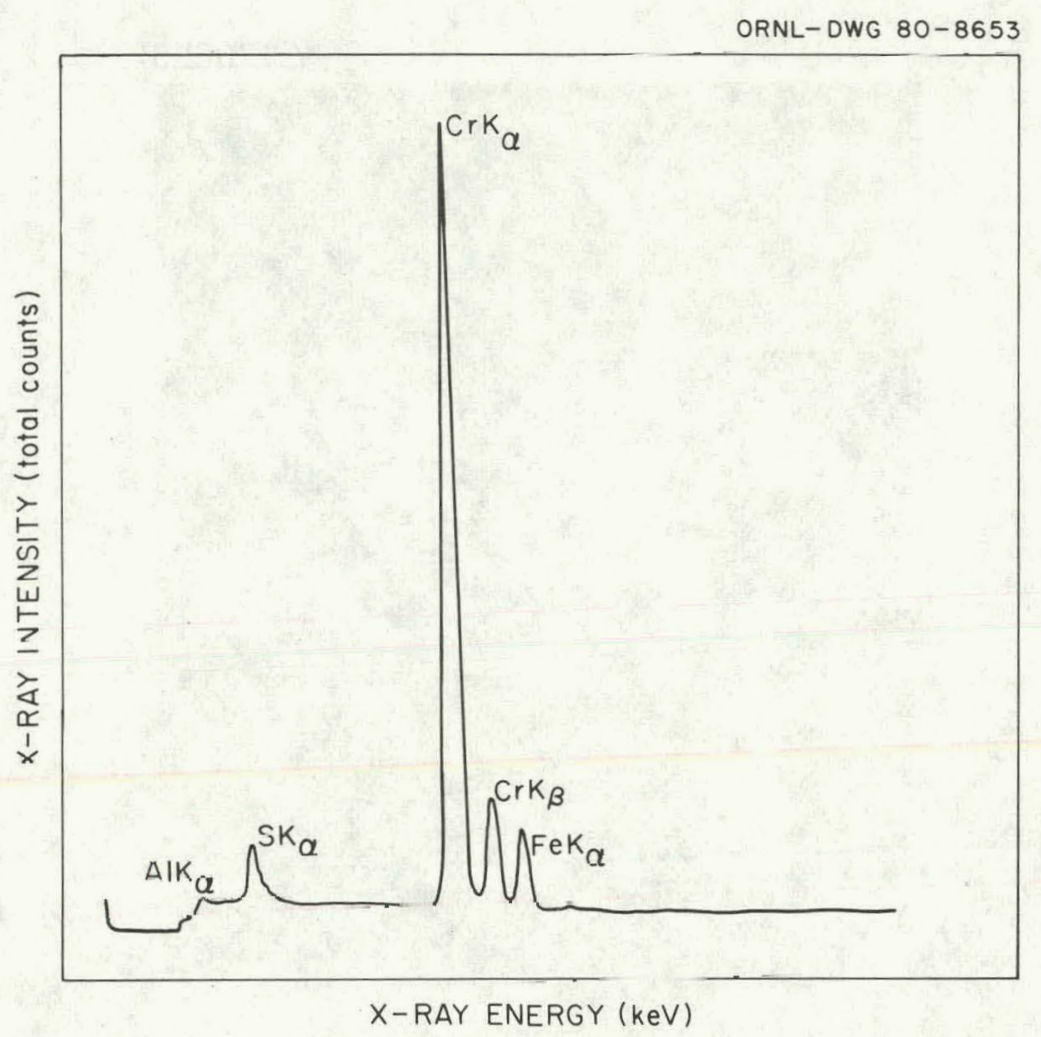

Fig. 11. Characteristic $x$-ray spectrum of region $B$ corrosion product in Fig. 9.

ORNL-OWG $80-8654$

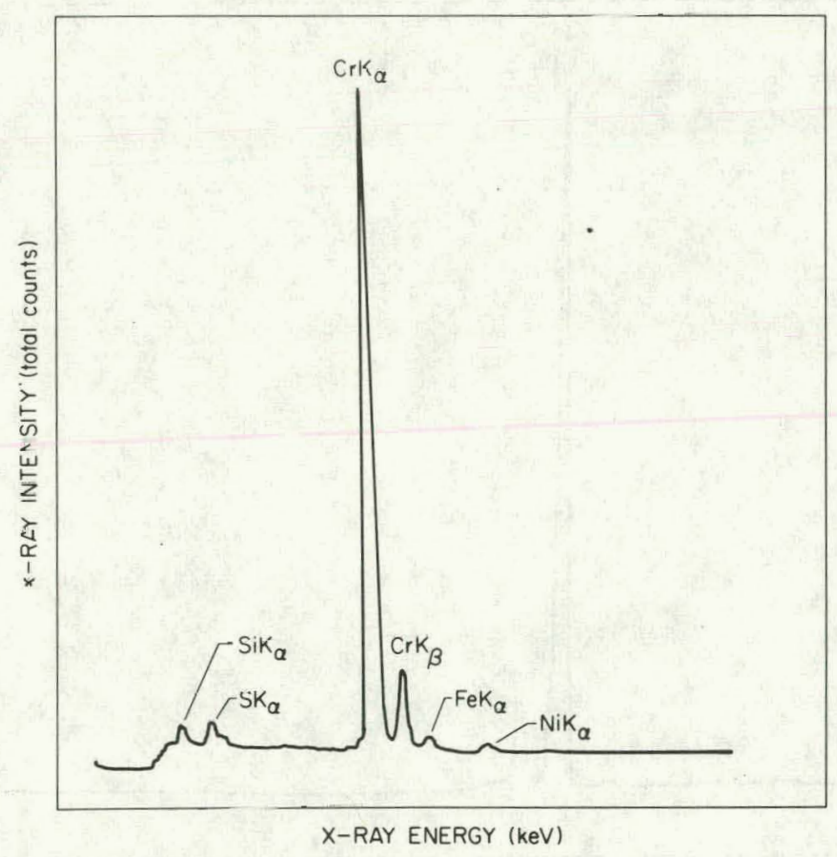

Fig. 12. Characteristic $\mathrm{x}$-ray spectrum of region $C$ corrosion product in Fig. 9. 


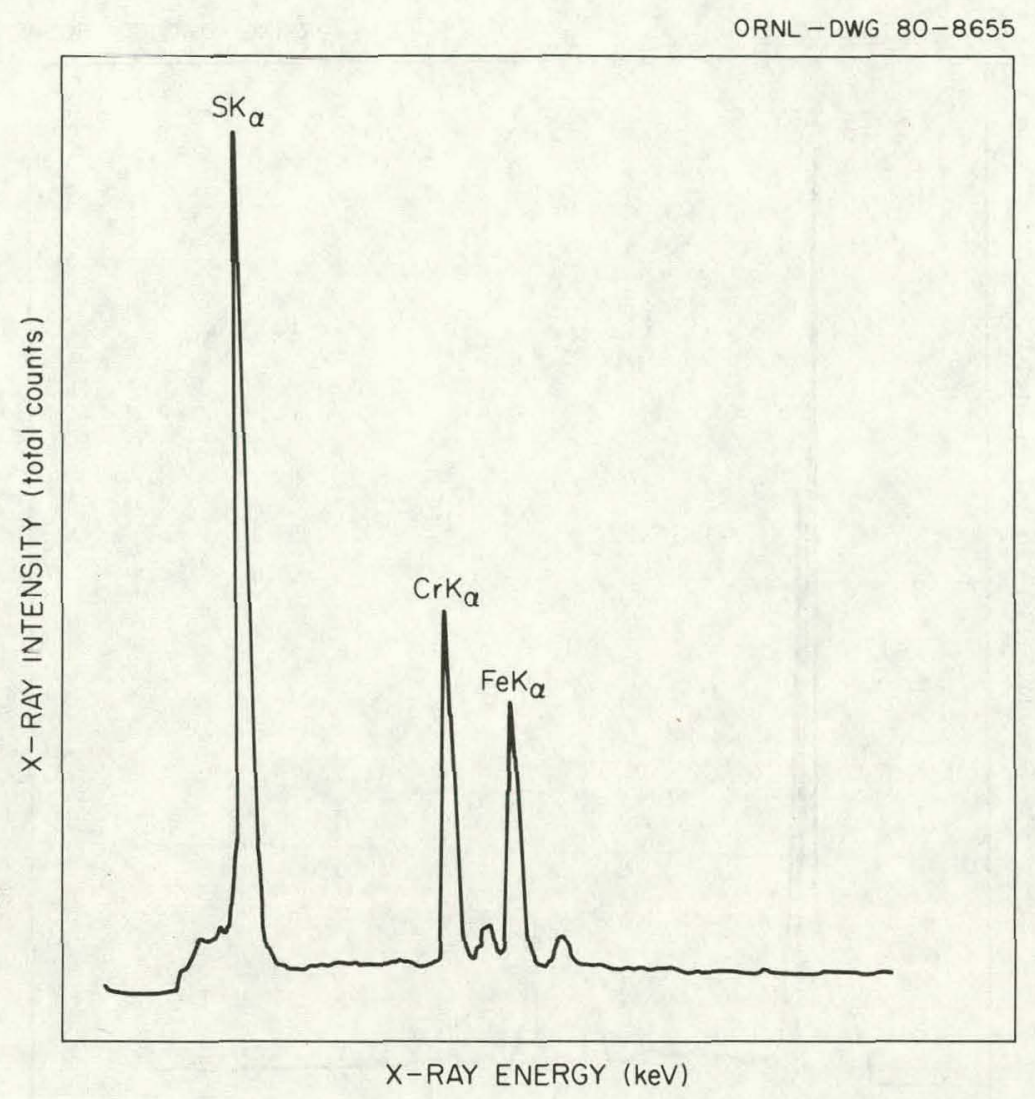

Fig. 13. Characteristic $x$-ray spectrum of region $D$ corrosion product in Fig. 9.

concentrations of the elements. These results, summarized in Table 5, show that the corrosion product was nonhomogeneous in composition. The electron microprobe used in this work could not detect elements with atomic number less than 11 (sodium); therefore, oxygen was not detected. $\mathrm{X}$-ray diffraction results, which were presented previously, showed the presence of iron and chromium oxides, so oxygen was certainly present in abundance. Table 5 shows that sulfur was found in substantial amount in several regions in the corrosion product. Since the concentration of sulfur was quite small relative to $\mathrm{Fe}, \mathrm{Cr}$, and $\mathrm{Ni}$ in the original type 309 stainless steel (see Table 2), the relatively high concentration of sulfur in the corrosion product was undoubtedly derived from the fuel oil combustion products and oil residues on scrap metal.

Figure 7 shows regions in the base metal of sample RI-3A that were also examined with the electron microprobe. The characteristic x-ray spectra for these regions are shown in Figs. 16 to 18. Figure 16 shows that the grain matrix contained $\mathrm{Fe}, \mathrm{Cr}$, and $\mathrm{Ni}$ in the approximate proportions expected for type 309 stainless stcel. Figure 17 shows that the attacked grain boundaries contained $\mathrm{S}, \mathrm{Cl}$, and $\mathrm{K}$ in addition to $\mathrm{Fe}, \mathrm{Cr}, \mathrm{Ni}$, and $\mathrm{Si}$. A characteristic $\mathrm{x}$-ray display for chlorine in Fig. 18 confirms the presence of chlorine in the grain boundaries. The role of these impurities on the corrosion of the alloy will be discussed later in this report.

Figure 19 shows the characteristic $\mathrm{x}$-ray spectrum for the grain precipitate in sample RI-3A. The precipitate was richer in chromium than was the surrounding grain material, as can be determined by comparison with Fig. 16. Since the grain boundaries in sample RI-3A were heavily attacked, we also examined the grain boundaries in sample RI-3B. Figure 20, the characteristic x-ray 


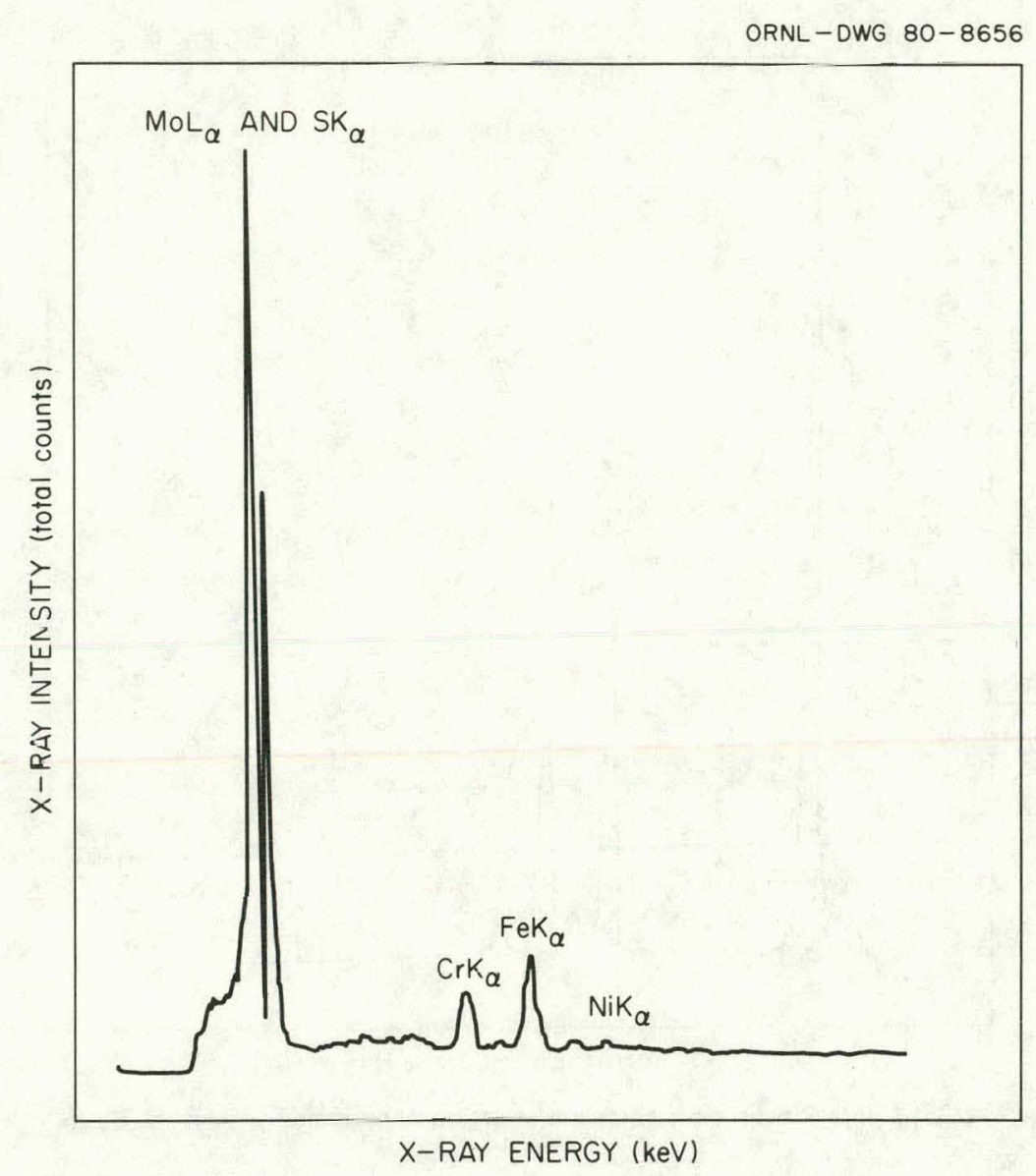

Fig. 14. Characteristic x-ray spectrum of region $E$ corrosion product in Fig. 9.

ORNL-DWG $80-8657$

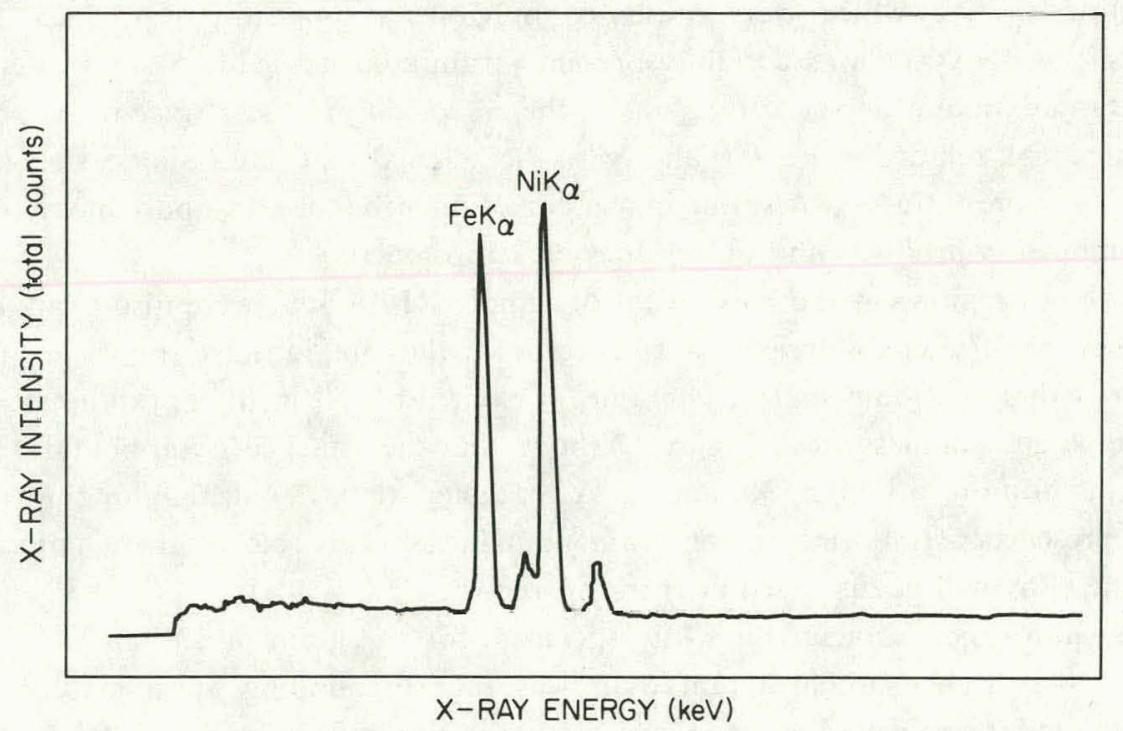

Fig. 15. Characteristic x-ray spectrum of region $F$ corrosion product in Fig. 9. 
Table 5. Summary of electron microprobe results on corrosion product on sample RI-3A

\begin{tabular}{clll}
\hline \multirow{2}{*}{$\begin{array}{c}\text { Region in } \\
\text { Fig. } 9\end{array}$} & \multicolumn{3}{c}{$\begin{array}{c}\text { Relative concentration of } \\
\text { identified elements }\end{array}$} \\
\cline { 2 - 4 } & High & Medium & Low \\
\hline$A$ & $\mathrm{Fe}$ & & \\
$B$ & $\mathrm{Cr}$ & $\mathrm{Fe}, \mathrm{S}$ & $\mathrm{Al}$ \\
$C$ & $\mathrm{Cr}$ & & $\mathrm{Fe}, \mathrm{Ni}, \mathrm{S}, \mathrm{Si}$ \\
$D$ & $\mathrm{Cr}, \mathrm{Fe}, \mathrm{S}$ & $\mathrm{Cr}, \mathrm{Fe}$ & $\mathrm{Ni}$ \\
$E$ & $\mathrm{~S}^{a}$ & & \\
$F$ & $\mathrm{Fe}, \mathrm{Ni}$ & & \\
\hline
\end{tabular}

${ }^{a}$ Since Mo $L \alpha$ peak coincides with $\mathrm{S} K \alpha$, some Mo may be present also.

ORNL-DWG $80-8658$

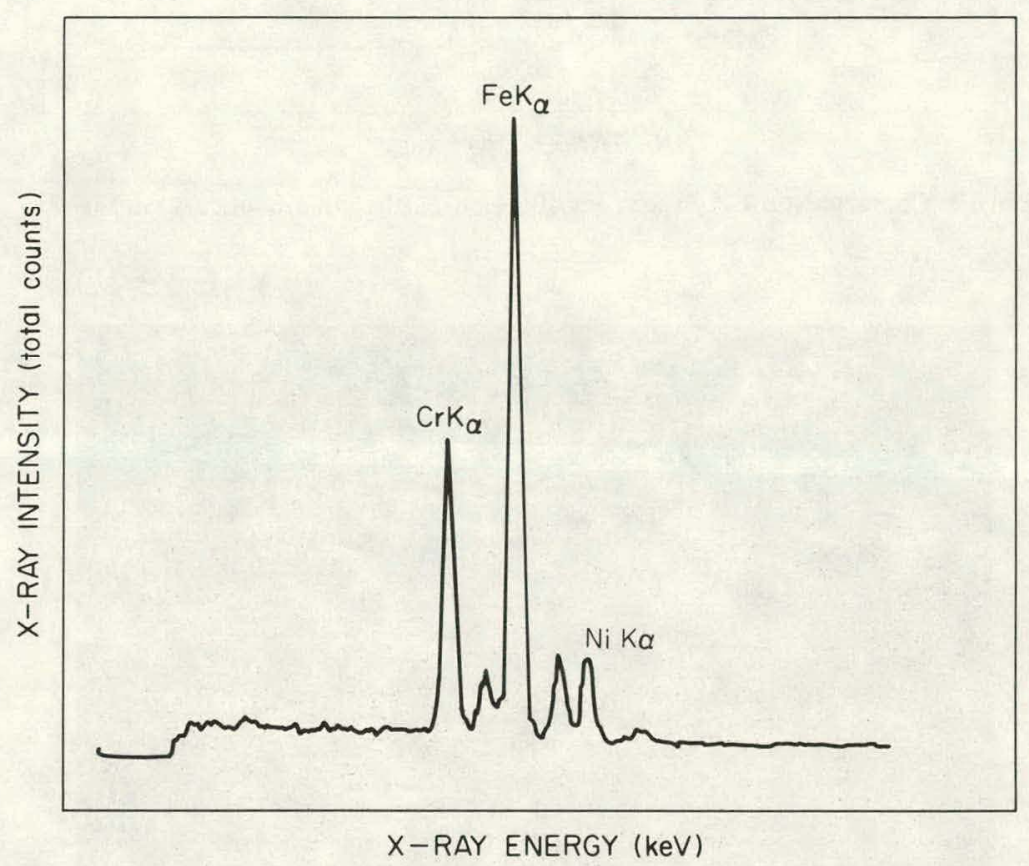

Fig. 16. Characteristic $x$-ray spectrum of region $G$ (the grain matrix) in Fig. 7 .

spectrum, shows that the grain boundaries also were richer in chromium than was the grain material. Precipitates faintly visible in as-polished samples (Fig. 7) were more clearly shown by etching. Figure 21 shows the etched microstructures of samples RI-3A and RI-3B in regions just beyond the severely attacked boundaries. These photographs show extensive grain-boundary precipitates and isolated precipitates within the grains. A special stain etch and $\mathrm{x}$-ray diffraction showed that these were carbide precipitates, prohahly $\mathrm{Cr}_{23} \mathrm{C}_{6}$. Precipitation was more extensive in sample RI-3A than in RI-3B, as can be determined by comparison of Fig. $21 b(500 \times)$ with Fig. $21 d(1500 \times)$. The presence of these carbide precipitates indicates either that the temperature at this location did not exceed $\sim 90 U^{\circ} \mathrm{C}\left(1650^{\circ} \mathrm{F}\right)$ duing the final hours of recuperator operation or that the recuperator cooled slowly in the range 900 to $500^{\circ} \mathrm{C}$. Under normal conditions, carbides dissolve in the matrix at temperatures greater than $900^{\circ} \mathrm{C}$. Similar precipitates were observed in other samples from the reradiant inserts and the partition wall. 


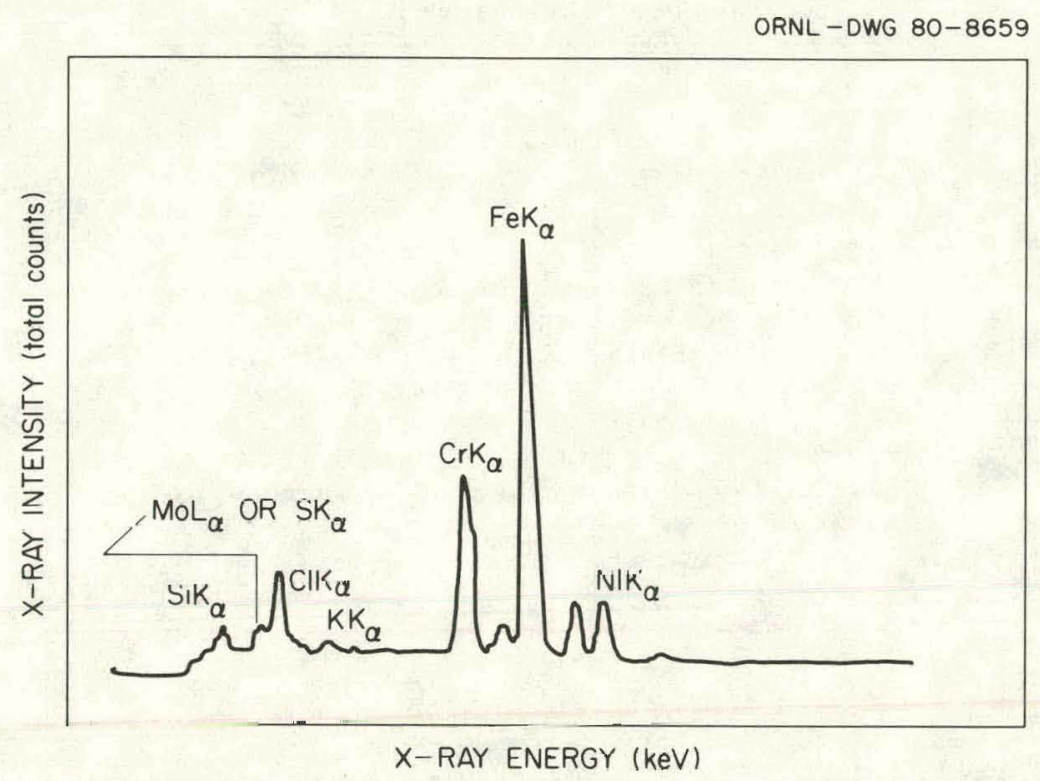

Fig. 17. Characteristic x-ray spectrum of region $H$ (the grain boundary) in Fig. 7.

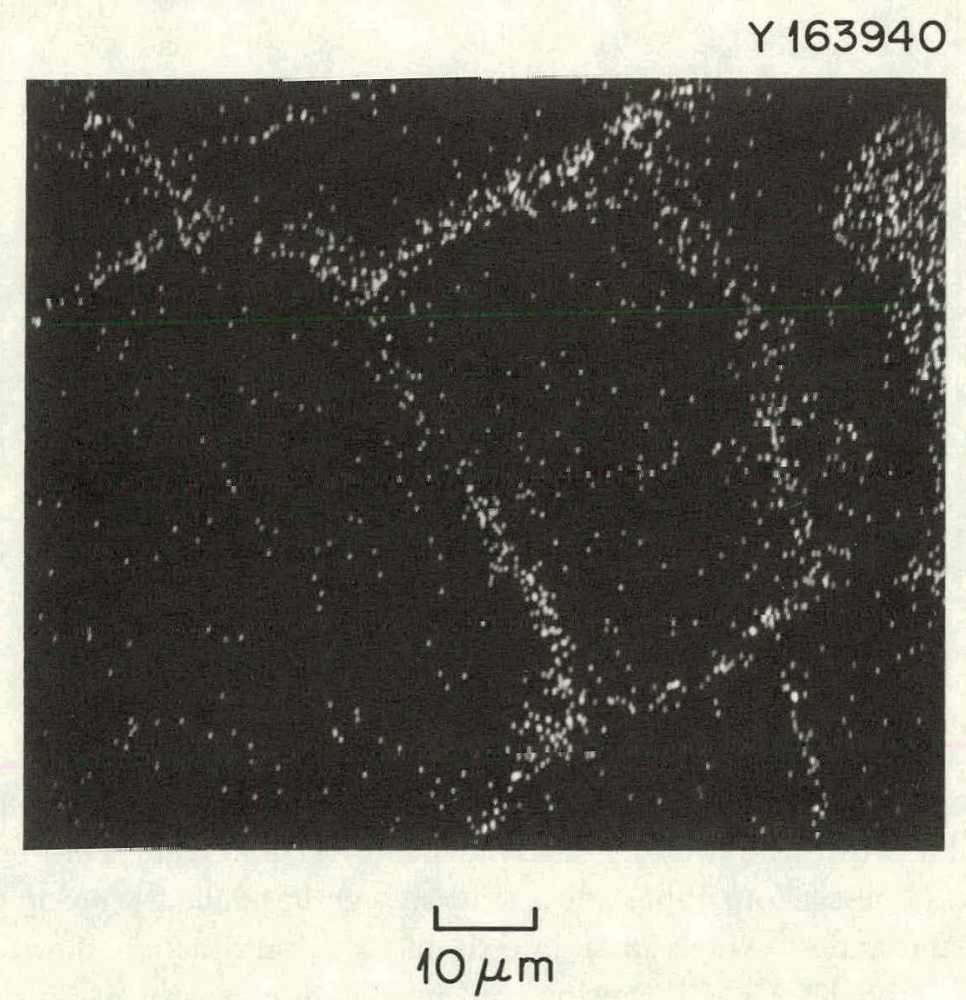

Fig. 18. Characteristic $\mathrm{x}$-ray display in sample RI-3A, showing chlorine at the grain boundaries. 


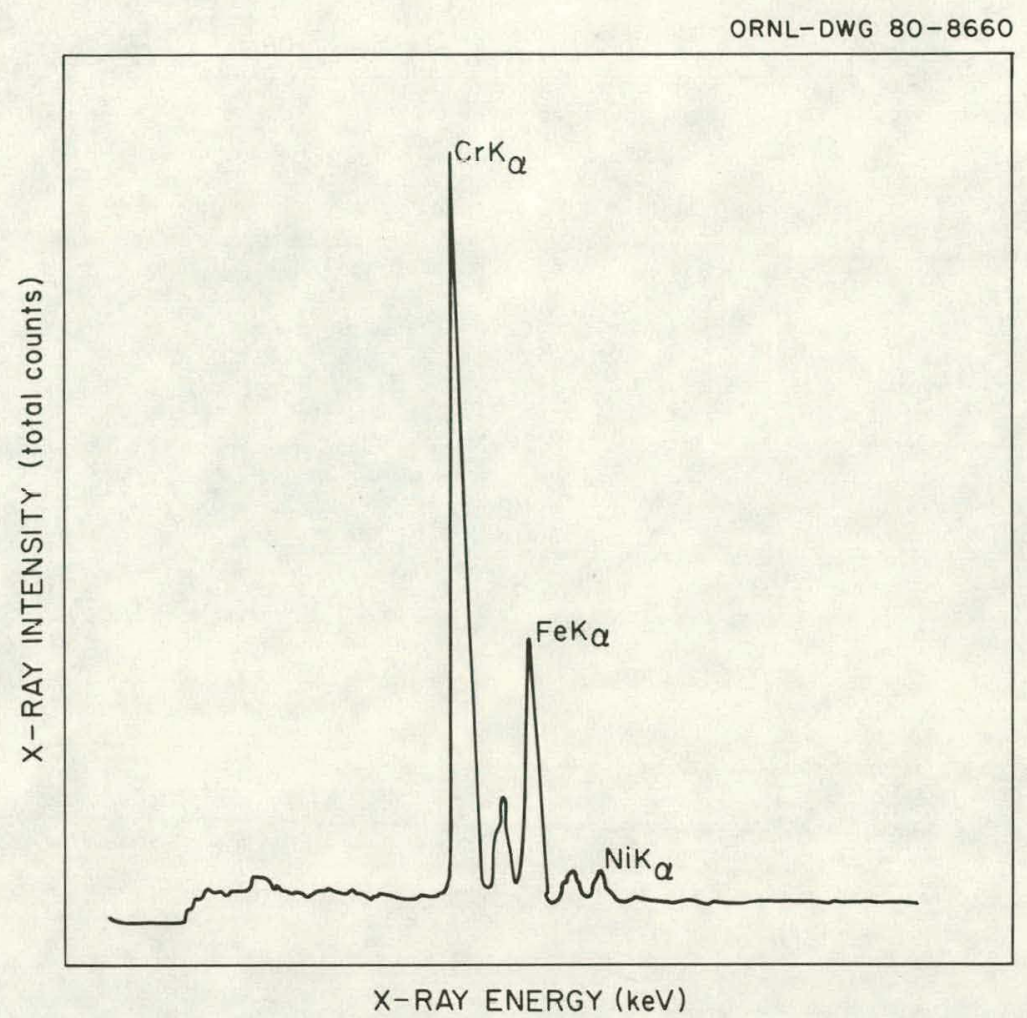

Fig. 19. Characteristic $x$-ray spectrum of region $I$ (the grain precipitate) in Fig. 7.

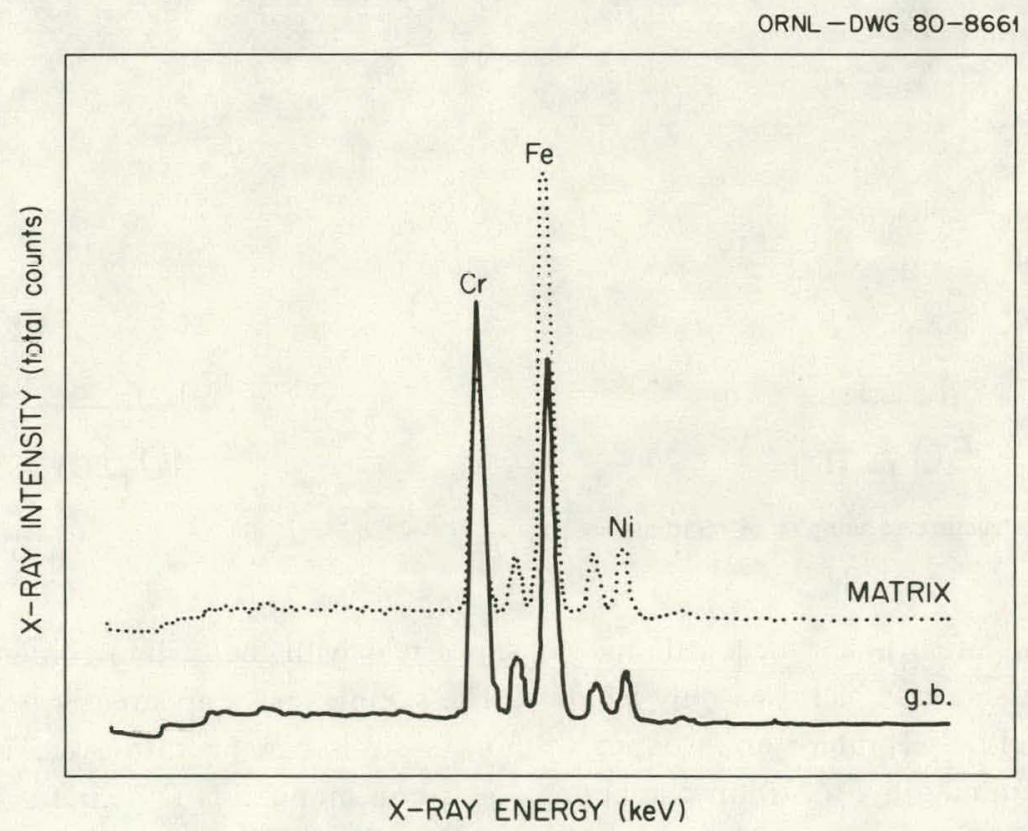

Fig. 20. Characteristic $x$-ray spectra of grains and grain boundaries in unattacked region of sample RI-3B (see Fig. 7). 

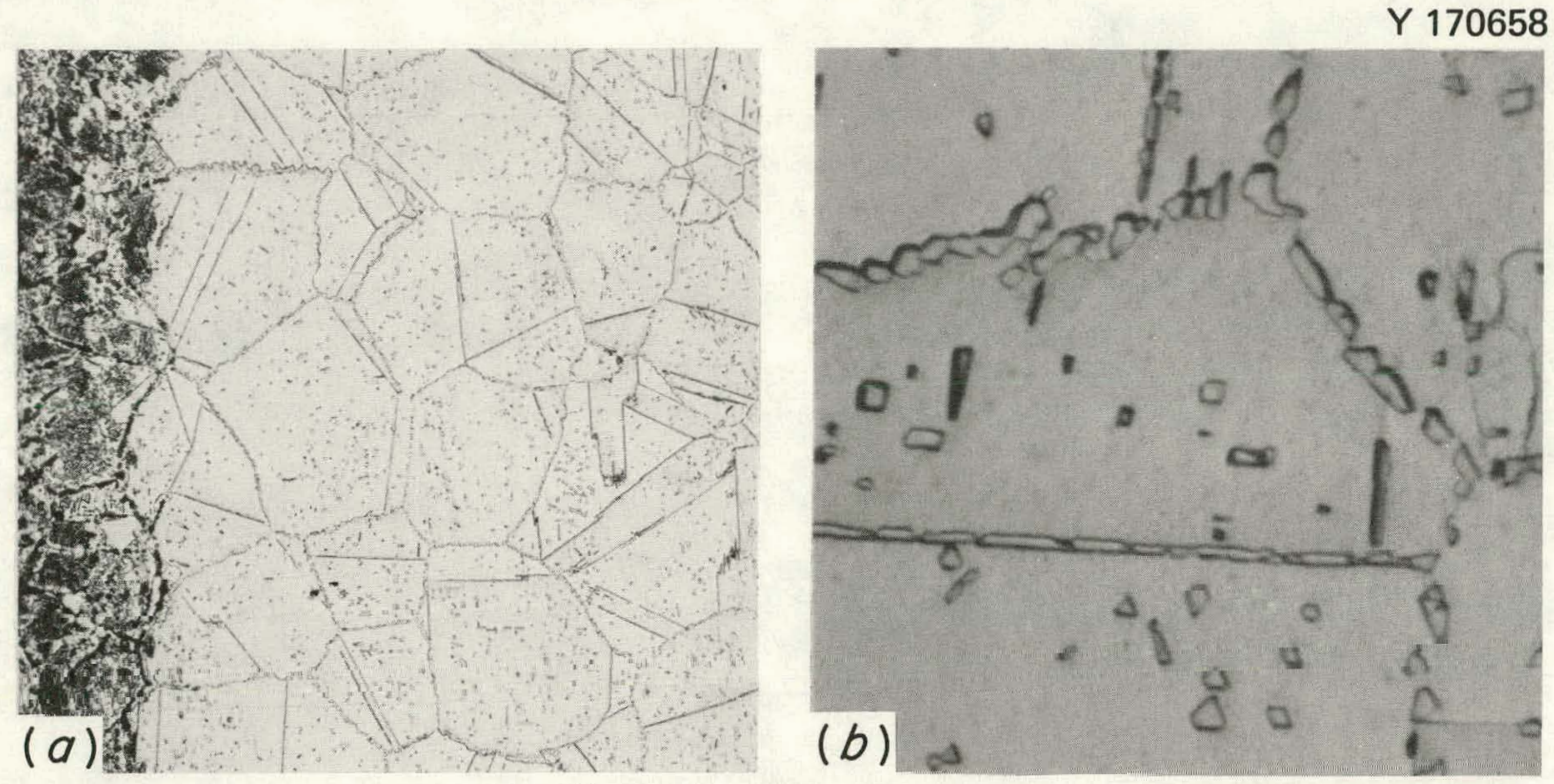
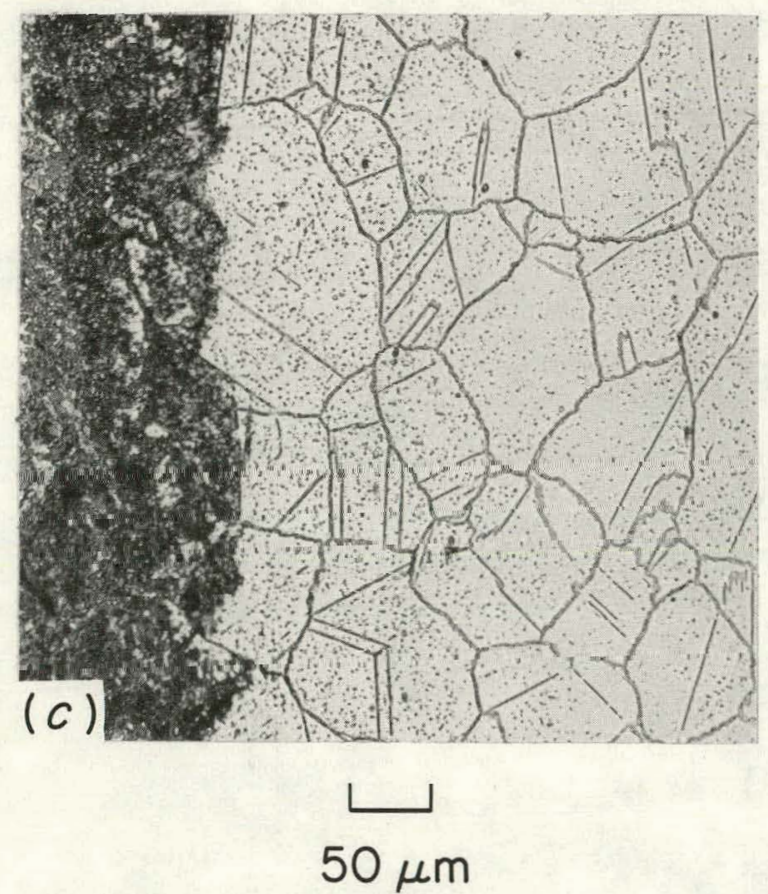
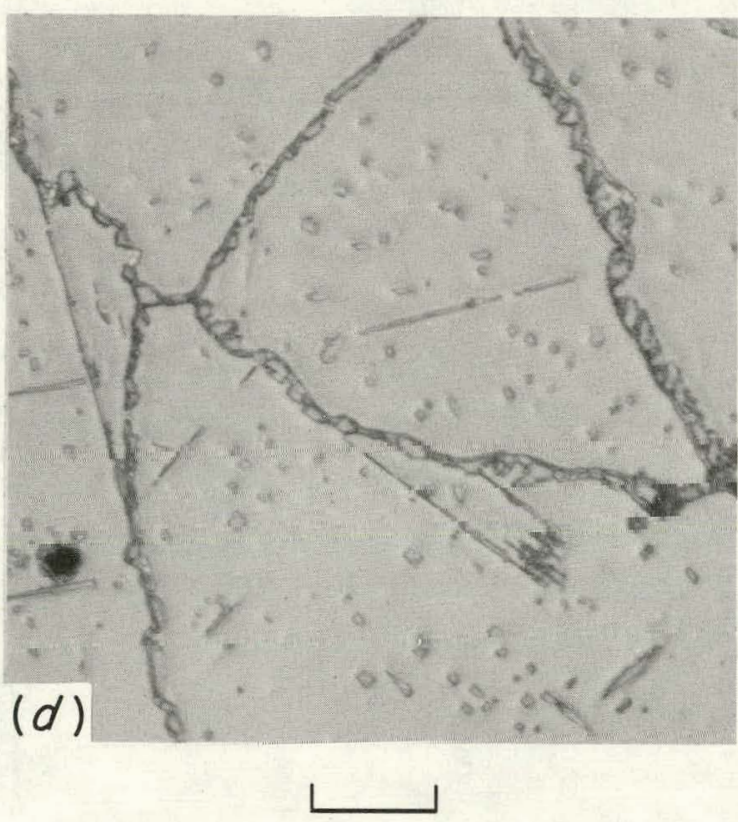

$10 \mu \mathrm{m}$

Fig. 21. Microstructure of samples of reradiant insert. (a) RI-3A, 200X; (b) RI-3A, 500X; (c) RI-3B, 200×; (d) RI-3B,

I he amount of carbide precipitation is not consistent with the carbon content of the original type 309 stainless steel, which was only $\sim 0.07 \%$. The samples have apparently been carburized by exposure to fuel-rich combustion products. Stainless steels can be carburized by heating in an atmosphere containing hydrocarbon compounds or cabon monoxide. Oil vapors, of course, would contain carbonaceous compounds. In the case of austenitic stainless steels, carburization is particularly detrimental if the carbon is subsequently precipitated as carbide. Much of the carbon combines with chromium to form chromium carbide, $\mathrm{Cr}_{23} \mathrm{C}_{6}$, and the adjacent matrix, depleted in chromium, is less resistant to corrosion in many environments. 
An electron microprobe study was also conducted on sample RI-24, which was initially located $\sim 7.3 \mathrm{~m}$ from the bottom of the recuperator. Figures 22 to 24 show characteristic x-ray spectra of three regions in the corrosion product. These regions are identified as points $L, M$, and $N$ in Fig. 7 . Figure 22 shows that the outermost layer of corrosion product (region $L$ ) contained $\mathrm{Fe}$ and $\mathrm{Ni}$ in approximately equal proportions, but the adjacent region $M$, shown in Fig. 23, contained $\mathrm{Fe}, \mathrm{Cr}$, Ni, and S. Figure 24 shows that region $N$ near the midthickness also contained $\mathrm{Fe}, \mathrm{Cr}, \mathrm{Ni}$, and $\mathrm{S}$, but in

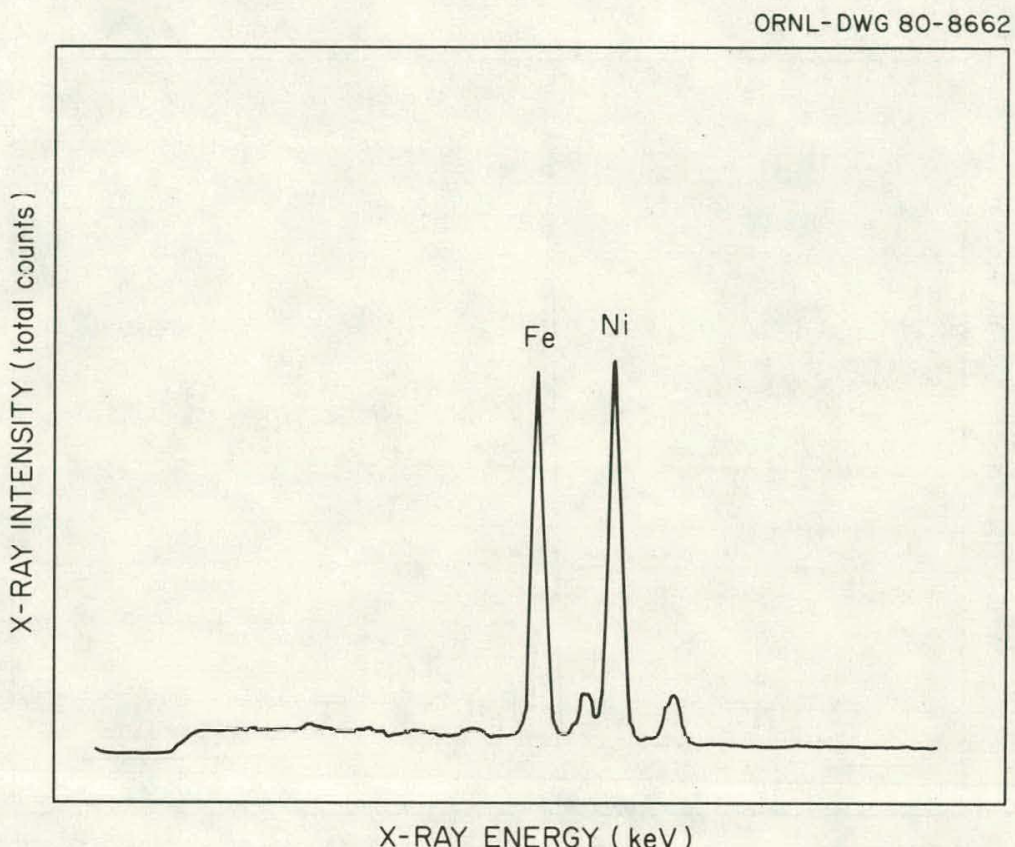

Fig. 22. Characteristic $x$-ray spectrum of region $L$ corrosion product in sample RI-24 in Fig. 7.

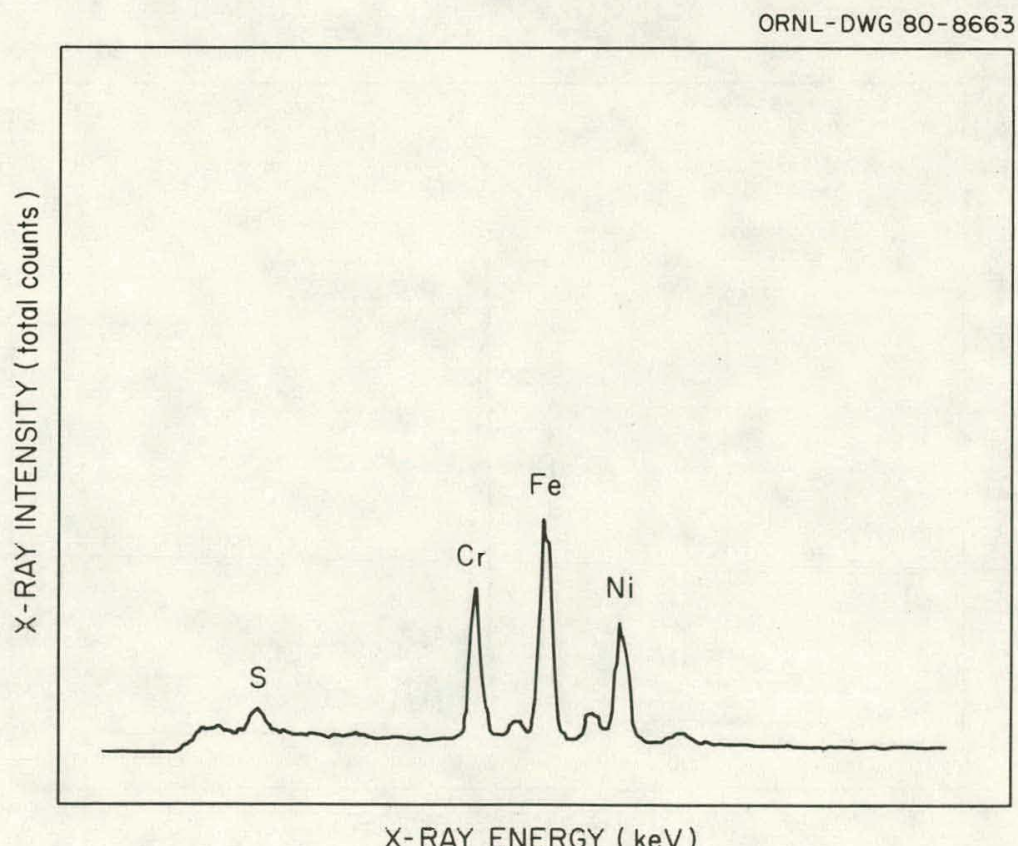

Fig. 23. Characteristic $\mathbf{x}$-ray spectrum of region $M$ corrosinn product in sample RI-24 in Fig. 7. 
this case $\mathrm{Cr}$ was the major element. Since regions adjacent to regions $L, M$, and $N$ often had different x-ray spectra, Figs. 22 to 24 should be considered to be examples of the heterogeneous nature of the corrosion product. Sulfur was usually found in these $\mathrm{x}$-ray spectra, indicating that this impurity was involved in the corrosion process.

Characteristic x-ray spectra of the intergranularly corroded base metal are shown in Figs. 25 to 27. Figure 25 shows that the grain interior (region $P$ ) contained $\mathrm{Fe}, \mathrm{Cr}$, and $\mathrm{Ni}$ as expected.

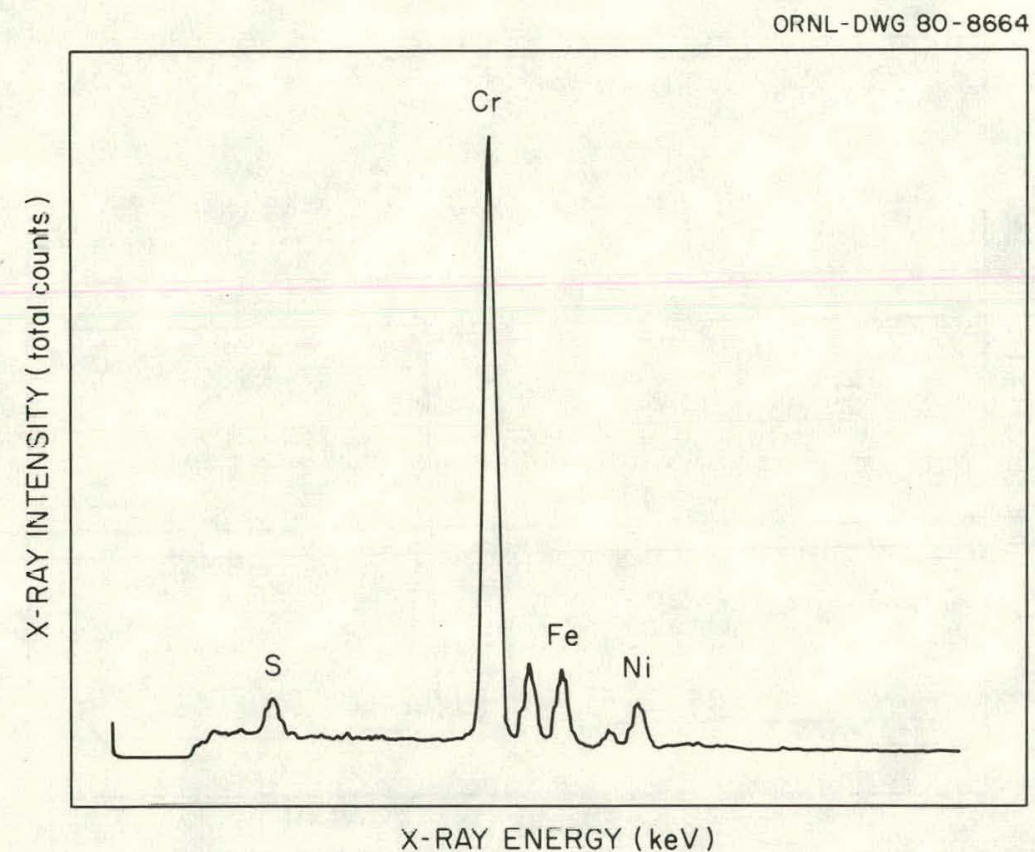

Fig. 24. Characteristic $\mathrm{x}$-ray spectrum of region $N$ corrosion product in sample RI-24 in Fig. 7.

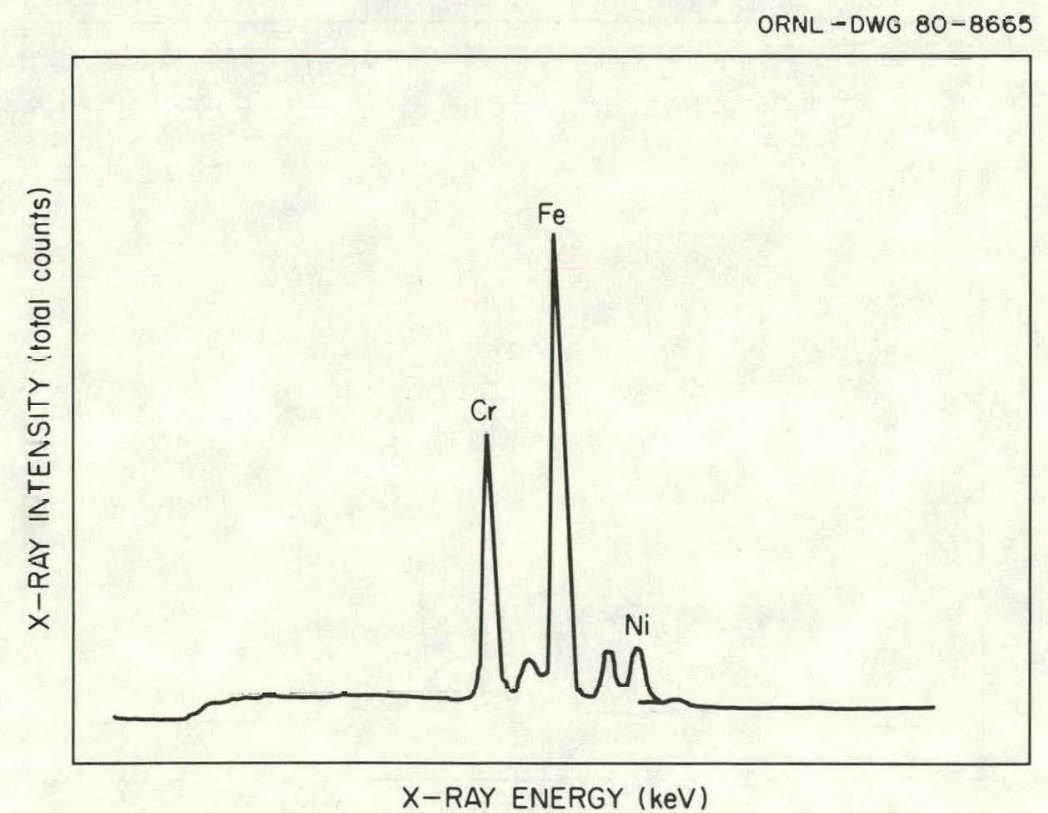

Fig. 25. Characteristic $\mathrm{x}$-ray spectrum of grain in region $\boldsymbol{P}$ in sample RI-24 in Fig. 7. 
Grain-boundary region $Q$, shown in Fig. 26, also contained $\mathrm{Fe}, \mathrm{Cr}$, and $\mathrm{Ni}$ (higher $\mathrm{Cr}$ concentration than in region $P$ ); and grain-boundary region $R$, shown in Fig. 27, contained $\mathrm{Fe}, \mathrm{Cr}, \mathrm{Ni}$, and $\mathrm{S}$. Characteristic $\mathrm{x}$-ray displays for $\mathrm{Cl}, \mathrm{K}$, and $\mathrm{S}$ shown in Fig. 28 reveal that these impurity elements were concentrated in the grain boundaries in the intergranularly attacked material.

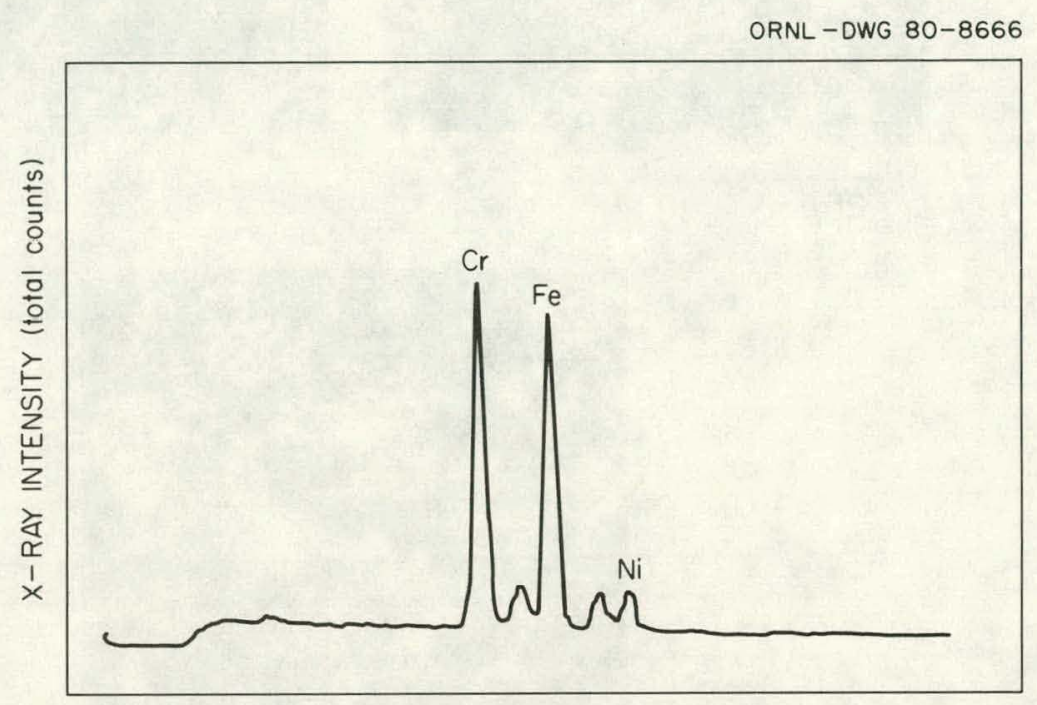

$X-$ RAY ENERGY (keV)

Fig. 26. Characteristic $\mathrm{x}$-ray spectrum of grain-boundary region $Q$ in sample RI-24 in Fig. 7.

.

ORNL-DWG $80-8667$

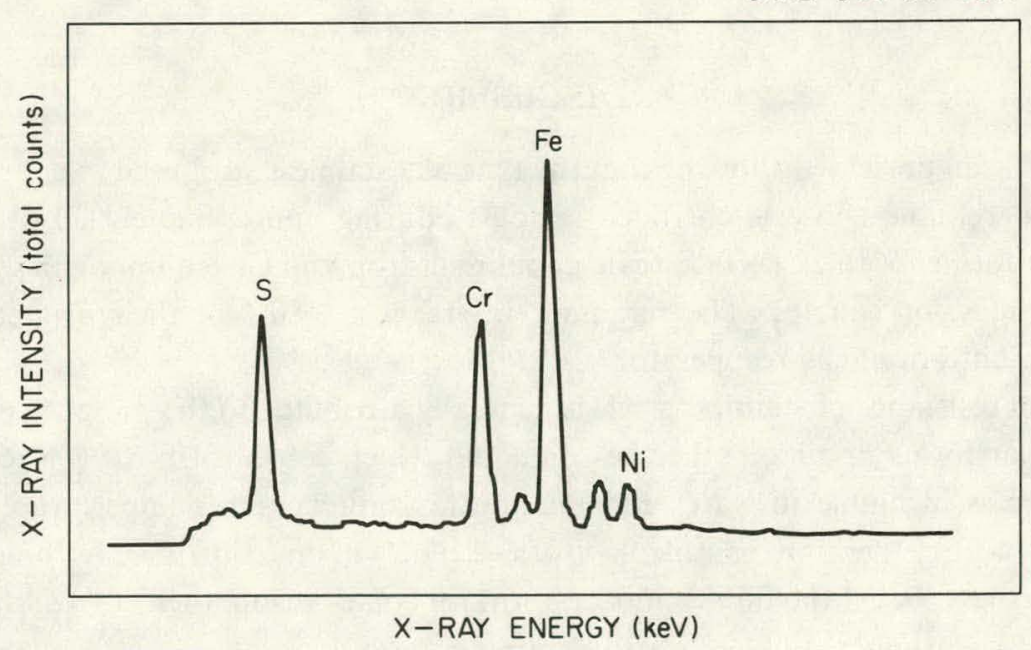

Fig. 27. Characteristic $\mathrm{x}$-ray spectrum of grain-boundary region $R$ in sample RI-24 in Fig. 7. 


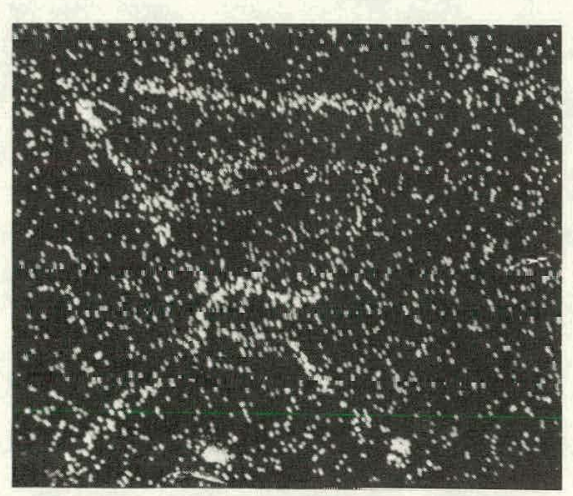

$\mathrm{Cl}$
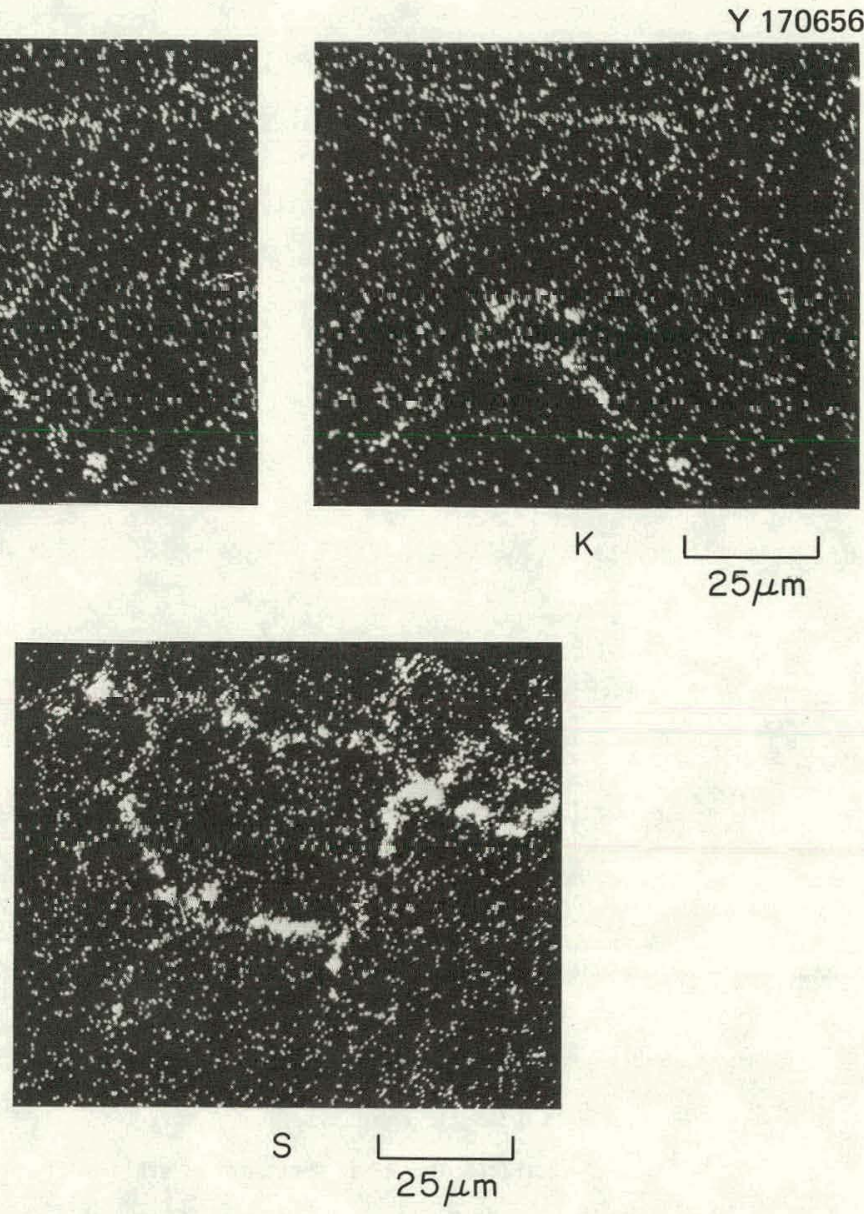

Fig. 28. Characteristic $\mathrm{x}$-ray displays for $\mathrm{Cl}, \mathrm{K}$, and $\mathrm{S}$ in sample $\mathrm{RI}-24$.

\section{DISCUSSION}

Evidence has been presented showing that the type 309 stainless steel used in construction of the partition wall and reradiant inserts corroded seriously during approximately $30 \mathrm{~d}$ of service. The corrosion process formed a thick surface scale contaınıng iron and chromium oxides and, probably, other oxides, sulfides, or sulfates. The reradiant inserts lost $>80 \%$ of their original thickness in locations near the bottom of the recuperator.

The corrosion resistance of stainless steels is generally attributed to the presence of an extremely thin oxide film that forms in air or other gas or liquid which can furnish oxygen to the surface. ${ }^{1,2}$ This adherent film is insoluble in water and many other liquids and is impermeable to these and many gases. Such a film, therefore, is called a "passive film." In an oxidizing environment the film is self-repairing if broken, but if the film cannot re-form for some reason, then corrosion will continue.

Type 309 is an austenitic stainless steel containing chromium and nickel in such amounts that the structural form is almost always face-centered cubic austenite. The martensitic and ferritic stainless steels contain chromium, but no nickel or only relatively small amounts. The austenitic types have the best high-temperature strength and resistance to scaling (oxidation) of the stainless steels. The passive oxide film on chromium steels ( $14 \% \mathrm{Cr}$ or more) and stainless steels is associated with 
the presence of chromium. The oxide film on stainless steels is enriched in $\mathrm{Cr}_{2} \mathrm{O}_{3}$, and the resistance to scaling increases with chromium content. ${ }^{3}$ Austenitic steels containing $>25 \% \mathrm{Cr}$ resist scaling at temperatures up to $1100^{\circ} \mathrm{C}\left(2010^{\circ} \mathrm{F}\right) .^{3}$ Experience shows that austenitic stainless steels containing $25 \% \mathrm{Cr}$ are not seriously corroded in hot oxidizing gases containing sulfur; ${ }^{2,4}$ however, incomplete combustion in an oxygen-starved atmosphere containing sulfur may result in damage or loss of the protective oxide film and corrosion of the alloy. ${ }^{5}$

Although extensive corrosion occurred in this recuperator, type 309 stainless steel was a proper choice as the material of construction under "normal" conditions. The corrosion in this particular case was caused by unusual conditions which the steel could not tolerate. Probably no other iron- or nickel-based material of construction could resist corrosion under the same conditions. The Incoloy $800 \mathrm{H}$ alloy, which contains more nickel (33\%) than does type 309 stainless steel, was used as angle brackets on the reradiant inserts, and this alloy also corroded badly. A eutectic in the Ni-S system at $645^{\circ} \mathrm{C}\left(1193^{\circ} \mathrm{F}\right)$ discourages use of high-nickel alloys in sulfur-containing atmospheres. The unusual conditions in the case of this recuperator occurred when the air/fuel ratio of the oil burner was not being controlled because of failure of the oil valve. As a result, the recuperator and reradiant inserts were exposed to unburned fuel and to high temperatures when the unburned fuel was ignited by extra air forced into the recuperator by a dilution air fan. A break in the partition wall, probably caused by excessive temperatures, allowed some combustion air to escape into the flue gases. The furnace operators noticed the decrease in the amount of combustion air. During the diagnostic period the air/fuel ratio may have varied between oxygen rich and fuel rich as the furnace operators used the appearance of the flame as a guide in adjusting the oil and air flows to maintain the required temperature and a near-stoichinmetric fuel mixture. Some thermal cycling of the recuperator may have occurred during this period. Thermal cycling would promote corrosion by causing the surface scale to crack and spall, thereby exposing fresh metal surface for attack by the flue gases.

The available evidence indicates that the corrosion mechanism was sulfidation-oxidation. This corrosion process, which has been described by Stringer and Whittle $^{6}$ and by. Stringer, ${ }^{7}$ has been observed in iron- and nickel-based alloys in fludized-bed combustors and in utility equipment using fossil fuels. Corrosion is governed by the thermodynamic stability of the oxides and sulfides of the elements involved. Figure 29 shows the limiting oxygen and sulfur partial pressures for stability of $\mathrm{Cr}_{2} \mathrm{O}_{3}$ and $\mathrm{CrS}$ at tcmpcratures of $\sim 870$ and $\sim 1100^{\circ} \mathrm{C}$. These temperatures are used for illustrative purposes and do not necessarily refer to actual known temperatures in the recuperator. Since the oil flame temperature is estimated to be $\sim 2100^{\circ} \mathrm{C}^{8}$, the temperatures used in Fig. 29 are not unreasonable. This type of diagram was calculated by Hemmings and Perkins, ${ }^{9}$ who have also constructed similar diagrams for $\mathrm{Fe}, \mathrm{Ni}$, and $\mathrm{Mn}$ at different temperatures. If the combustion products at $870^{\circ} \mathrm{C}$, for example, contained $p_{\mathrm{O}_{2}}>10^{-21} \mathrm{~Pa}$ and $p_{\mathrm{S}_{2}}<10^{-8} \mathrm{~Pa}$, the stable phase would be $\mathrm{Cr}_{2} \mathrm{O}_{3}$. In the case of stainless steel, the oxide film would contain $\mathrm{Cr}_{2} \mathrm{O}_{3}$ and would be protective. The value of $p_{\mathrm{O}_{2}}$ decreases from the ambient value to $10^{-21} \mathrm{~Pa}$ at the $\mathrm{Cr}-\mathrm{Cr}_{2} \mathrm{O}_{3}$ interface (or the stainless steel-oxide film interface). If the oxide film on the stainless steel is completely transparent to sulfur, then the value of $p_{\mathrm{S}_{2}}$ at the interface would equal the ambient value. Thus an increase in $p_{\mathrm{s}_{2}}$ in the combustion products could shift the equilibrium at the interface in favor of $\mathrm{CrS}$ instead of $\mathrm{Cr}_{2} \mathrm{O}_{3}$. This is equivalent to loss of the protective oxide film, and without the protective film the alloy corrodes relatively rapidly.

Some characteristics of this type of corrosion have been described by Stringer and Whittle. ${ }^{6}$ Sulfides form ahead of the oxidation front and prevent formation of a continuous protective oxide 


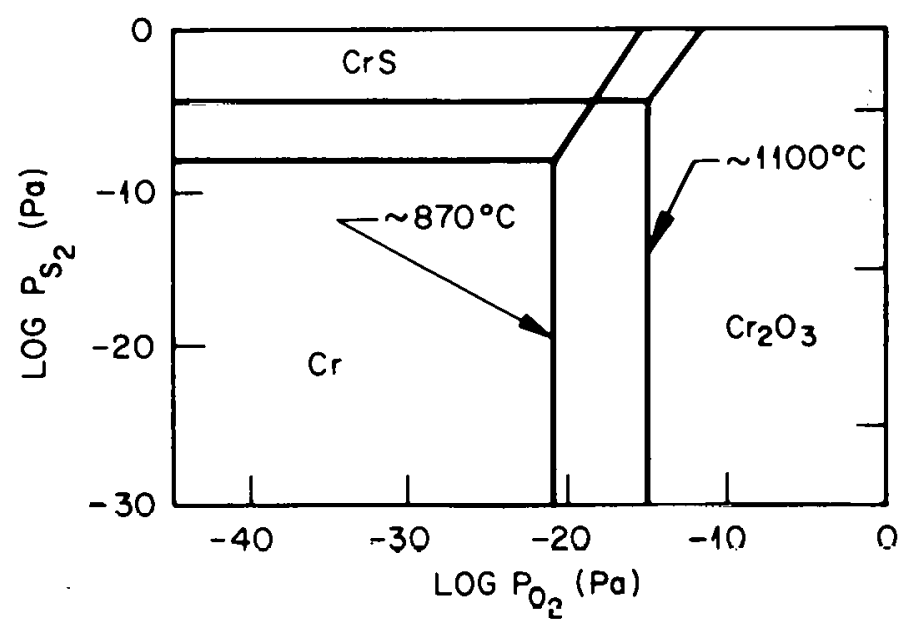

Fig. 29. Phase relationships in the $\mathrm{Cr}-\mathrm{O}-\mathrm{S}$ system.

film. As a result the alloy oxidizes. A self-perpetuating situation develops when oxidation of the sulfides releases sulfur, which diffuses further into the alloy and forms more sulfides.

In tests conducted in a coal-fed fluidized-bed combustor, a variety of iron-, nickel-, and cobalt-based alloys (including austenitic stainless steels) were exposed to fluidizing gases containing 300 to $400 \mathrm{ppm} \mathrm{SO} \mathrm{S}_{2}$ at temperatures up to $\sim 900^{\circ} \mathrm{C}^{7}$ Sulfides were detected beneath the surface of each of the alloys. The stainless steels exhibited a fairly uniform band or zone containing discrete particles. Sume of the nickel- and cobalt-based alloys exhibited cxtcnsive grain-boundary penetration of sulfides. These alloys had thick scales with sulfides beneath the oxide.

The above description of the sulfidation-oxidation process and the cited examples of this type of corrosion are consistent with the results presented in this analysis. In the present case the elements needed for enhanced corrosion were most likely present: chromium carbide precipitates at grain boundaries, making adjacent regions sensitive to intergranular attack because of chromium depletion; fluctuations in oxygen and sulfur potentials in the flue gases, resulting in low-oxygen-high-sulfur conditions; thermal cycling, resulting in spalling of the surface scale; and the presence of chlorine in the flue gases.

So far, the role of chlorine in corrosion of this material has not been discussed. Chlorine, potassium, and sodium, evidently carry-over from the salt flux mixture charged with the aluminum scrap, were found in the corrosion product, while chlorine and potassium were found in the intergranularly corroded metal. Investigations have shown that halides cause corrosion of stainless steels and nickel-based alloys under certain conditions. Seybolt ${ }^{10}$ observed that destructive internal oxidation or grain-boundary attack occurred when these materials were alternately dipped in an $\mathrm{NaCl}$ (or $\mathrm{Nal}, \mathrm{NaBr}, \mathrm{NaF}$ ) solution then heated to a temperature in the range 800 to $1000^{\circ} \mathrm{C}$ in air. Such corrosion resulted in a penetration rate of $\sim 7 \mathrm{~nm} / \mathrm{s}(0.001 \mathrm{in} . / \mathrm{h})$. Seybolt made two other important observations: (1) the halides were more destructive when the exposure temperature was above their melting points, and (2) tests with compounds such as $\mathrm{NaOH}$ and $\mathrm{NaHCO}_{3}$ showed that sodium ions did not enhance corrosion.

In another investigation, ${ }^{1}$ several nickel- and iron-based alloys, including austenitic stainless steels, were exposed to a fluidized-bed combustion environment to evaluate the effects of $\mathrm{NaCl}$ and 
$\mathrm{CaCl}_{2}$ on corrosion. Test temperatures ranged between 450 and $950^{\circ} \mathrm{C}$, and the atmosphere contained $5 \% \mathrm{O}_{2}$ and up to $500 \mathrm{ppm} \mathrm{SO}_{2}$. The salts prevented formation of the normally protective oxide film. As a result, corrosion rates were higher than observed in the absence of salt. Corrosion was attributed to a combination of internal oxidation and sulfidation.

\section{SUMMARY AND CONCLUSIONS}

A concentric-tube recuperator with reradiant inserts on an aluminum-melting furnace recovered heat from the furnace flue gases and delivered heated combustion air to the furnace, which was heated with No. 2 fuel oil. Aluminum scrap and a mixture of halide salts constituted the furnace charge; however, the salts were supposedly confined to the charging zone by a furnace bridge wall. After about $30 \mathrm{~d}$ of operation, during which the recuperator delivered combustion air at $\sim 540^{\circ} \mathrm{C}$ $\left(1000^{\circ} \mathrm{F}\right)$ to the furnace, changes in operating characteristics were noted. During a diagnostic period of several days, data indicated a break in the partition wall of the recuperator which allowed some combustion air to be lost to the flue gases. The partition wall and reradiant inserts were probably exposed to flue gases containing less than the normal amount of oxygen, partially burned fuel, higher than normal temperatures, and temperature fluctuations. The recuperator was then shut down, and an inspection revealed excessive corrosion of the partition wall and inserts as well as buckling and breaking of the partition wall.

Our analysis revealed the following:

1. Chemical analyses confirmed that the material of construction for the partition wall and reradiant inserts was type 309 stainless steel as intended.

2. Metallographic examination of samples along the entire length of the partition wall and reradiant inserts revealed extensive corrosion characterized by surface scale and intergranular attack of the alloy directly under the scale.

3. X-ray diffraction patterns revealed that the surface scale contained iron and chromium oxides (and other unidentified compounds), while chemical analysis showed that the scale also contained $\mathrm{Cl}, \mathrm{K}, \mathrm{Na}$, and $\mathrm{S}$.

4. Electron microprobe analysis showed that precipitates in the grains and grain boundaries of unattacked alloy were rich in chromium (relative to the matrix), and both a stain etch and $x$-ray diffraction showed that the precipilales weie carbide, probably $\mathrm{Cr}_{23} \mathrm{C}_{8}$.

5. Electron microprobe analysis revealed the presence of $\mathrm{Cl}, \mathrm{K}$, and $\mathrm{S}$ in intergranularly attacked grain boundaries.

We concluded that the corrosion mechanism was primarily sulfidation-oxidation in which low-oxygen-high-sulfur atmospheres resulted in formation of sulfides under conditions in which the steel could not maintain a normally protective oxide film. In addition, chlorides in the flue gases contributed to corrosion by further reducing the ability of the steel to form a protective oxide film.

\section{RECOMMENDATIONS}

The results presented and the conclusions concerning the corrosion mechanism for the alloy in this recupcrator suggest several courses of action which, we believe, would greatly decrease the potential for corrosion of type 309 stainless steel in future recuperators. 
Test specimens of candidate alloys should be systematically exposed to hot flue gases prior to actual installation of the recuperator to determine whether particularly corrosivc conditions exist. The specimens should be located in positions which present the most severe conditions of temperature and flue gas composition likely to be encountered in recuperator scrvice. The flue gases should be continuously monitored for oxygen, combustibles, and sulfur-bearing gases so that any corrosion observed can later be directly correlated with the atmospheric exposure of the recuperator.

In cases where the recuperator is already installed or in use, we recommend that combustion be carefully controlled so that the flue gases always contain excess oxygen. The oxygen content of the flue gases should be as high as practical and never less than about $5 \%$ by volume. Continuous monitoring of the oxygen level and the combustible content of the flue gas at the inlet to the recuperator should also be done in conjuction with a control system, including automatic means of adding extra air to the recuperator when the oxygen level decreases below about $5 \%$. Finally, chlorides should be prevented from entering the recuperator if at all possible, since the detrimental effect of such compounds is well documented. These rernmmendations are intended to cmphasize. the need for complete combustion of fuel, having excess oxygen in the flue gases, and an absence of chlorides in the flue gases.

\section{REFERENCES}

1. J. H. G. Monypenny, Stainless Iron and Steel, 3d ed., vol. 1, Chapman and Hall, London, 1951, p. 228.

2. D. Peckner and I. M. Bernstein, Handbook of Stainless Steels, McGraw-Hill, New York, 1977, p. 16-2.

3. Metals Handbook, 1948 ed., The American Society for Metals, Cleveland, Ohio, p. 561.

4. Peckner and Bernstein, p. 17-24.

5. Monypenny, p. 375.

6. J. Stringer and D. P. Whittle, High Temperature Corrosion of Metals and Alloys in Fluidized Bed Combustor Environments, presented to the International VGB Conference on Corrosion and Deposition in Power Plants, Essen, June 1-2, 1977, to be published.

7. J. Stringer, "High-Temperature Corrosion of Metals and Alloys in Fluidized-Bed Combustion Systems," Proceedings of the Fifth International Conference on Fluidized-Bed Combustion, Vol. III, Development Activities, Dec. 12-14, 1977, Washington, D.C., pp. 682-98.

8. P. Keith Ellis, Reynolds Metals Co., private communication.

9. P. L. Hemmings and R. A. Perkins, Lockheed Paln Alto Research Laboratories, Report to the Electric Power Research Institute on Project No. RP 716-1 (March 1977).

10. A. V. Seybolt, "Internal Oxidation in Heat-Resisting Stainless Steels Caused by Presence of Halides," Oxid. Met. 2(2), 161-71 (1970).

11. Materials Technology for Coal Conversion Processes, Fifteenth Quarterly Repart, ANL-79-2 (July-September 1978), pp. 37-56. 
Table A-1. Phases in corrosion product RD-1 determined by $\mathrm{x}$-ray diffraction

\begin{tabular}{|c|c|c|c|}
\hline \multirow{2}{*}{ RD-1 } & \multicolumn{3}{|c|}{ Lattice spacing $(\mathrm{nm})$} \\
\hline & $\mathrm{Fe}_{2} \mathrm{O}_{3}$ & $\mathrm{Cr}_{3} \mathrm{O}_{4}$ & $\mathrm{Cr}_{2} \mathrm{O}_{3}$ \\
\hline \multicolumn{4}{|l|}{0.40065} \\
\hline $\begin{array}{l}0.36231 \\
0.35688\end{array}$ & 0.366 & & 0.3633 \\
\hline \multicolumn{4}{|l|}{0.35688} \\
\hline \multicolumn{4}{|l|}{0.29066} \\
\hline \multirow{2}{*}{\multicolumn{4}{|c|}{$\begin{array}{l}0.28729 \\
0.28096\end{array}$}} \\
\hline & & & \\
\hline \multicolumn{4}{|l|}{0.27883} \\
\hline \multicolumn{4}{|l|}{0.27631} \\
\hline 0.26780 & 0.269 & & 0.2666 \\
\hline \multicolumn{4}{|l|}{0.26262} \\
\hline \multicolumn{4}{|l|}{0.26018} \\
\hline 0.24987 & 0.251 & & 0.2480 \\
\hline \multicolumn{4}{|l|}{0.24642} \\
\hline \multirow{2}{*}{\multicolumn{4}{|c|}{0.24378}} \\
\hline 0.24213 & & & \\
\hline \multirow{2}{*}{\multicolumn{4}{|c|}{$\begin{array}{l}0.23921 \\
0.23812\end{array}$}} \\
\hline & & & \\
\hline \multicolumn{4}{|l|}{0.23128} \\
\hline \multicolumn{4}{|l|}{0.22936} \\
\hline 0.22880 & 0.2285 & & 0.2264 \\
\hline 0.21920 & 0.2201 & & \\
\hline \multirow{2}{*}{\multicolumn{4}{|c|}{0.21679}} \\
\hline & \multicolumn{3}{|c|}{0.21414} \\
\hline 0.20650 & 0.2070 & & \\
\hline \multicolumn{4}{|l|}{0.20273} \\
\hline \multirow{2}{*}{\multicolumn{4}{|c|}{$\begin{array}{l}0.20081 \\
0.19844\end{array}$}} \\
\hline \multirow{2}{*}{\multicolumn{4}{|c|}{$\begin{array}{l}0.19844 \\
0.19122\end{array}$}} \\
\hline & & & \\
\hline 0.18327 & 0.1838 & & 0.1816 \\
\hline 0.17929 & & & \\
\hline 0.17229 & & 0.1725 & \\
\hline 0.16876 & 0.1690 & & 0.1672 \\
\hline 0.16565 & & 0.1655 & \\
\hline 0.16488 & & & \\
\hline 0.16305 & 0.1634 & & \\
\hline 0.16182 & 0.1596 & 0.1590 & \\
\hline 0.15293 & & 0.1525 & \\
\hline 0.15144 & & & \\
\hline 0.14817 & 0.1484 & & \\
\hline 0.14609 & & & 0.1465 \\
\hline 0.14479 & 0.1452 & & \\
\hline 0.14415 & & 0.1432 & 0.1431 \\
\hline 0.14135 & & & \\
\hline 0.14028 & & & \\
\hline 0.13945 & & & \\
\hline 0.13786 & & & \\
\hline 0.13065 & 0.1310 & & 0.1296 \\
\hline 0,12887 & & $0.128 \%$ & \\
\hline 0.12692 & & & \\
\hline 0.12599 & 0.1258 & & \\
\hline
\end{tabular}


Table A-2. Phases in corrosion product RD-2 determined by $x$-ray diffraction

\begin{tabular}{|c|c|c|c|c|}
\hline \multirow{2}{*}{ RD-2 } & \multicolumn{4}{|c|}{ Lattice spacing (nm) } \\
\hline & $\mathrm{Fe}_{2} \mathrm{O}_{3}$ & $\mathrm{Fe}_{3} \mathrm{O}_{4}$ & $\mathrm{Cr}_{3} \mathrm{O}_{4}$ & $\mathrm{Cr}_{2} \mathrm{O}_{3}$ \\
\hline \multicolumn{5}{|l|}{0.40149} \\
\hline 0.36701 & 0.366 & & & 0.36 .3 \\
\hline \multicolumn{5}{|l|}{0.35928} \\
\hline \multicolumn{5}{|l|}{0.33948} \\
\hline \multicolumn{5}{|l|}{0.317 .32} \\
\hline 0.30685 & & & 0.305 & \\
\hline 0.29289 & & 0.2966 & & \\
\hline \multicolumn{5}{|l|}{0.27951} \\
\hline \multicolumn{5}{|l|}{0.27483} \\
\hline \multicolumn{5}{|l|}{0.27287} \\
\hline 0.26928 & 0.269 & & & \\
\hline \multicolumn{4}{|l|}{0.26457} & 0.2666 \\
\hline 0.261 .39 & & & 0.258 & \\
\hline 0.25142 & 0.251 & 0.2530 & & \\
\hline \multicolumn{4}{|l|}{ n $24 \times 13$} & $0.24 \overline{8} u$ \\
\hline 0.24429 & & & $\cdot$ & \\
\hline 0.21205 & & 0.2419 & & \\
\hline 0.23970 & & & 0.239 & \\
\hline 0.23278 & & & 0.234 & \\
\hline 0.23003 & $0.22 \times 5$ & & & \\
\hline 0.22079 & 0.2201 & & & \\
\hline 0.21804 & & & & \\
\hline 0.21774 & & & & 0.2176 \\
\hline $0.2,1455$ & & & 0.216 & \\
\hline 0.20804 & 0.2070 & 0.2096 & & \\
\hline 0.20368 & & & & 0.2048 \\
\hline 0.20102 & & & & \\
\hline 0.18654 & & & 0.190 & \\
\hline 0.18403 & 0.1838 & & & . \\
\hline 0.18217 & & & & 0.1816 \\
\hline 0.17956 & & & & \\
\hline 0.17277 & & 0.1712 & 0.1725 & \\
\hline 0.16919 & 0.1690 & & & 0.1672 \\
\hline 0.16540 & & & 0.1655 & \\
\hline 0.16345 & 0.1634 & & & \\
\hline 0.16171 & & 0.1614 & & \\
\hline 0.15909 & 0.1598 & & 0.1590 & \\
\hline 0.15787 & & & & 0.1579 \\
\hline 0.15500 & & & & \\
\hline 0.15337 & & & 0.1579 & \\
\hline 0.15111 & & & & \\
\hline 0.149 .37 & & & & \\
\hline 0.14843 & 0.1484 & 0.1483 & & \\
\hline 0.14693 & & & & 0.1465 \\
\hline 0.14485 & & & & \\
\hline 0.14295 & 0.1452 & & 0.14 .32 & 0.14 .31 \\
\hline 0.14154 & & & & \\
\hline 0.14004 & & & & \\
\hline 0.13782 & & & $\cdot$ & \\
\hline 0.13207 & & 0.1327 & & \\
\hline 0.13099 & 0.1310 & & & \\
\hline 0.12957 & & & 0.1287 & 0.1296 \\
\hline 0.12733 & & 0.1279 & $0.12 \times 0$ & \\
\hline 0.12592 & 0.1258 & 0.1264 & & 0.1240 \\
\hline 0.11894 & 0.1189 & & 0.1217 & \\
\hline 0.11746 & & & & $0.11 \overline{7.3}$ \\
\hline 0.11625 & 0.1162 & & & \\
\hline 0.11496 & & & & o. il149 \\
\hline 0.11400 & 0.1141 & & & \\
\hline 0.11327 & & 0.11214 & & 0.1124 \\
\hline 0.110 .34 & 0.1102 & & & \\
\hline 0.10842 & & 0.10922 & & 0.1087 \\
\hline 0.1075 .3 & 0.1076 & & & \\
\hline 0.10716 & & & & \\
\hline U.106s8 & & & & \\
\hline 0.10608 & 0.1055 & & & \\
\hline 0.10411 & 0.1042 & 0.10489 & & 0.1042 \\
\hline 0.10184 & & & & \\
\hline 0.10041 & & & & \\
\hline
\end{tabular}


Table A-3. Phases in corrosion product RD-3 determined by $x$-ray diffraction

\begin{tabular}{|c|c|c|c|c|}
\hline \multirow{2}{*}{ RD-3 } & \multicolumn{4}{|c|}{ Lattice spacing $(\mathrm{nm})$} \\
\hline & $\mathrm{Fe}_{2} \mathrm{O}_{3}$ & $\mathrm{Fe}_{3} \mathrm{O}_{4}$ & $\mathrm{Cr}_{3} \mathrm{O}_{4}$ & $\mathrm{Cr}_{2} \mathrm{O}_{3}$ \\
\hline 0.48425 & & 0.485 & & \\
\hline 0.47450 & & $\cdot$ & 0.478 & \\
\hline \multicolumn{5}{|l|}{0.46130} \\
\hline \multicolumn{5}{|l|}{0.40221} \\
\hline \multicolumn{5}{|l|}{0.39864} \\
\hline \multicolumn{5}{|l|}{0.38031} \\
\hline 0.36187 & 0.366 & & & 0.3633 \\
\hline \multicolumn{5}{|l|}{0.35477} \\
\hline \multicolumn{5}{|l|}{0.31104} \\
\hline \multicolumn{5}{|l|}{0.30521} \\
\hline \multicolumn{5}{|l|}{0.29159} \\
\hline \multicolumn{5}{|l|}{0.28630} \\
\hline \multicolumn{5}{|l|}{0.28156} \\
\hline \multicolumn{5}{|l|}{0.27815} \\
\hline 0.26733 & 0.269 & & & 0.2666 \\
\hline \multicolumn{5}{|l|}{0.26511} \\
\hline \multicolumn{5}{|l|}{0.26292} \\
\hline 0.24933 & 0.251 & 0.2530 & & 0.2480 \\
\hline \multicolumn{5}{|l|}{0.24169} \\
\hline \multicolumn{5}{|l|}{0.23970} \\
\hline 0.23157 & & & 0.234 & \\
\hline 0.22824 & 0.2285 & & & 0.2264 \\
\hline 0.21920 & 0.2201 & & & \\
\hline 0.21684 & & & 0.216 & 0.2176 \\
\hline 0.21270 & & & & \\
\hline 0.20794 & 0.2070 & 0.2096 & & \\
\hline 0.20298 & & & & 0.2048 \\
\hline 0.19984 & & & & \\
\hline 0.19717 & & & 0.190 & \\
\hline $0: 18302$ & 0.1838 & & & 0.1816 \\
\hline 0.18099 & & & & \\
\hline 0.16928 & & 0.1712 & 0.1725 & \\
\hline 0.16894 & 0.1690 & & & \\
\hline 0.16865 & & & & \\
\hline 0.16768 & & & & 0.1672 \\
\hline 0.16666 & & & & \\
\hline 0.16491 & & & 0.1655 & \\
\hline 0.16255 & 0.1634 & 0.1614 & & \\
\hline 0.15956 & 0.1596 & & 0.1590 & 0.1579 \\
\hline 0.15483 & & & & \\
\hline 0.15302 & & & $\dot{U} .1525$ & \\
\hline 0.15033 . & 0.1484 & 0.1483 & & \\
\hline 0.14664 & & & & 0.1465 \\
\hline 0.14501 & 0.1452 & & & \\
\hline 0.14467 & & & & \\
\hline 0.14312 & & & 0.1432 & 0.1431 \\
\hline 0.14131 & & & & \\
\hline 0.13989 & & & & \\
\hline 0.13121 & 0.1310 & 0.1327 & & \\
\hline 0.12949 & & & 0.1287 & 0.1296 \\
\hline 0.12663 & & 0.1264 & 0.1280 & \\
\hline 0.12575 & 0.1258 & & & \\
\hline 0.12051 & & 0.1211 & & 0.1210 \\
\hline 0.12023 & & & & \\
\hline 0.11974 & 0.1189 & & & \\
\hline $0: 11968$ & & & & \\
\hline 0.11600 & & & & \\
\hline 0.11470 & & & & 0.1149 \\
\hline
\end{tabular}


Table A-4. Phases in corrosion product RD-4 determined by $x$-ray diffraction

\begin{tabular}{|c|c|c|c|c|}
\hline \multirow{2}{*}{$\mathrm{RD}-4$} & \multicolumn{4}{|c|}{ Lattice spacing $(\mathrm{nm})$} \\
\hline & $\mathrm{Fe}_{2} \mathrm{O}_{3}$ & $\mathrm{Fe}_{3} \mathrm{O}_{4}$ & $\mathrm{Cr}_{3} \mathrm{O}_{4}$ & $\mathrm{Cr}_{2} \mathrm{O}_{3}$ \\
\hline 0.48955 & & 0.485 & & \\
\hline 0.47677 & & & 0.478 & \\
\hline \multicolumn{5}{|l|}{0.44106} \\
\hline \multicolumn{5}{|l|}{0.40437} \\
\hline \multicolumn{5}{|l|}{$0.381 \mathrm{I}$} \\
\hline 0.36376 & 0.366 & & & 0.3633 \\
\hline \multicolumn{5}{|l|}{0.32364} \\
\hline \multicolumn{5}{|l|}{0.31578} \\
\hline 0.30582 & & & 0.305 & \\
\hline \multicolumn{5}{|l|}{0.29177} \\
\hline 0.28191 & & & 0.286 & \\
\hline 0.27665 & & & & \\
\hline 0.26788 & 0.269 & & & 0.2666 \\
\hline 0.26314 & & & 0.258 & \\
\hline 0.25027 & 0.251 & 0.253 & & 0.2480 \\
\hline \multicolumn{5}{|l|}{0.24422} \\
\hline 0.24282 & & 0.2119 & & \\
\hline 0.23982 & & & 0.239 & \\
\hline 0.23180 & 0.2285 & & 0.234 & 0.22 .64 \\
\hline 0.21941 & 0.2201 & & 0.216 & 0.2176 \\
\hline 0.20772 & 0.2070 & 0.2096 & & \\
\hline 0.20307 & & & & 0.2048 \\
\hline \multicolumn{5}{|l|}{0.19877} \\
\hline \multicolumn{5}{|l|}{0.18589} \\
\hline 0.18313 & 0.1838 & & & \\
\hline \multicolumn{3}{|l|}{0.18085} & & 0.1816 \\
\hline 0.17253 & & 0.1712 & 0.1725 & \\
\hline \multicolumn{5}{|l|}{0.16974} \\
\hline 0.16828 & 0.1690 & & & 0.1672 \\
\hline 0.16518 & & & 0.1655 & 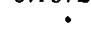 \\
\hline 0.16311 & 0.1634 & & & \\
\hline 0.16007 & 0.1596 & 0.1614 & 0.1590 & \\
\hline \multicolumn{5}{|l|}{0.15118} \\
\hline 0.15318 & & & 0.1525 & \\
\hline 0.14710 & 0.1484 & 0.1483 & & 0.1465 \\
\hline 0.14479 & 0.1452 & & & \\
\hline \multicolumn{5}{|l|}{0.11154} \\
\hline 0.13179 & 0.1310 & & & \\
\hline 0.13015 & & 0.1279 & & 0.1296 \\
\hline \multicolumn{5}{|l|}{0.12702} \\
\hline 0.12552 & 0.1258 & & & 0.1240 \\
\hline 0.12197 & 0.1226 & & 0.1217 & \\
\hline 0.12037 & 0.1213 & 0.1211 & & 0.1210 \\
\hline 0.11816 & 0.1189 & & & \\
\hline 0.11597 & 0.1162 & & & \\
\hline 0.11498 & & & & 0.1149 \\
\hline 0.11348 & 0.1141 & & & 0.1124 \\
\hline 011126 & & 0.1121 & & \\
\hline 0.10987 & 0.1102 & 0.1092 & & \\
\hline 0.10845 & & & & 0.1087 \\
\hline 0.10727 & 0.1076 & & & \\
\hline 0.10511 & 0.1055 & 0.1049 & & \\
\hline 0.10414 & 0.1042 & & & 0.1042 \\
\hline 0.10195 & & & & \\
\hline 0.09955 & & & & \\
\hline 0.09823 & 0.09890 & 0.09890 & & \\
\hline 0.09619 & 0.09601 & & & \\
\hline
\end{tabular}


Table A-5. Phases in corrosion product RD-5 determined by $\mathbf{x}$-ray diffraction

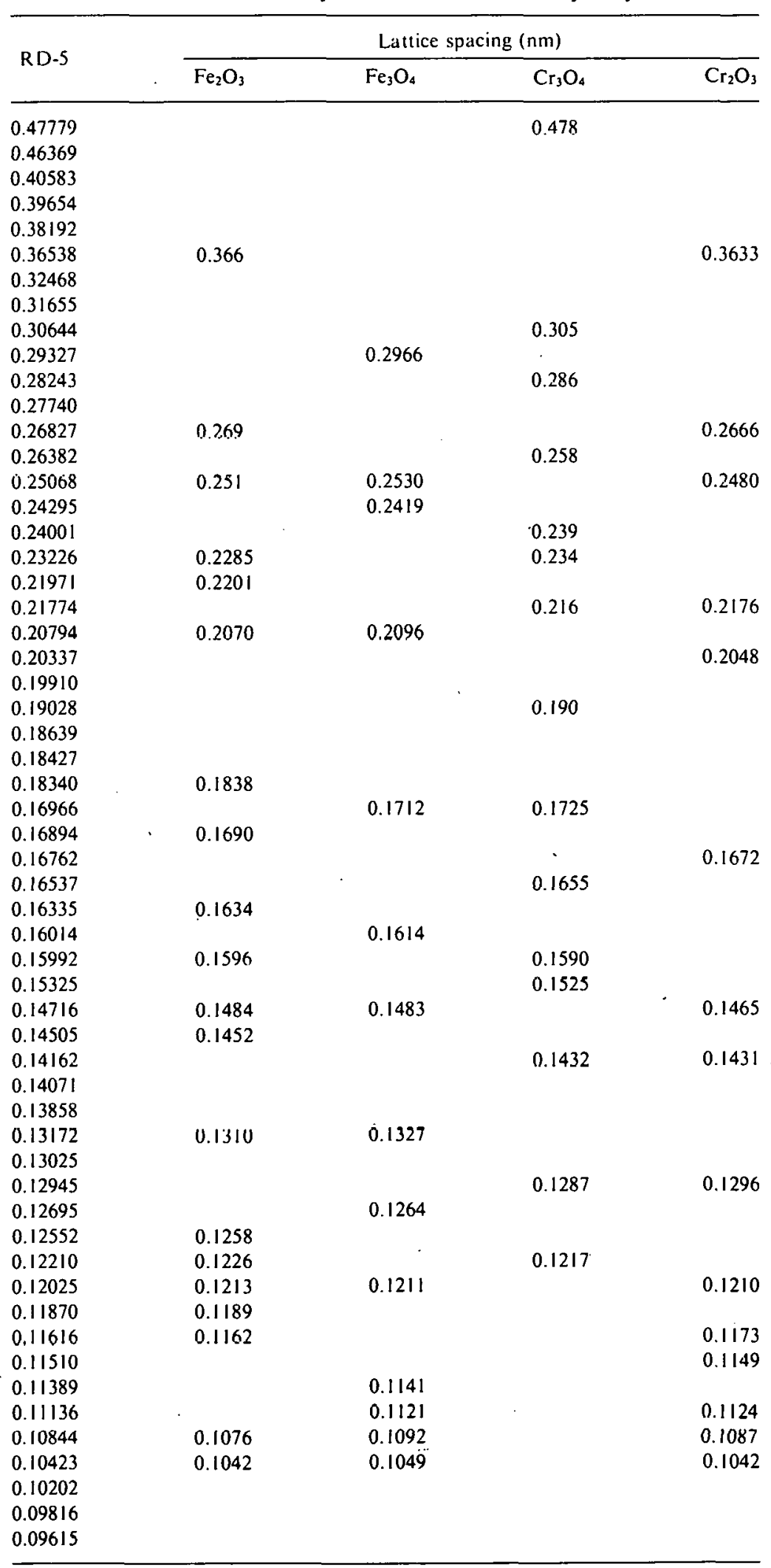


Appendix

SUMMARY OF CRYSTALLINE PHASES IDENTIFIED IN CORROSION PRODUCT 


\section{ORNL/TM-7166}

\section{INTERNAL DISTRIBUTION}

1-2. Central Research Library

3. Document Reference Section

4-5. Laboratory Records Department

6. Laboratory Records, ORNL R.C.

7. ORNL Patent Section

8. R. L. Beatty

9. R. A. Bradley

10. G. W. Brassell

11. R. S. Carlsmith

12. P. T. Carlson

13. J. V. Cathcart

14. R. G. Donnelly

15-19. J. I. Federer

20. G. R. Gessel

21. R. J. Gray

22. J. C. Griess

23. T. G. Godfrey

24. Bahman Heshmatpour
25-27. M. R. Hill

28. C. T. Liu

29. P. L. Maziasz

30. L. E. McNeese

31. A. E. Pasto

32. R. E. Pawel

33. P. L. Rittenhouse

34-38. A. C. Schaffhauser

39. J. E. Selle

40. G. M. Slaughter

41-51. V. J. Tennery

52. T. N. Tiegs

53. G. C. Wei

54. A. L. Bement, Jr. (Consultant)

55. W. R. Hibbard, Jr. (Consultant)

56. E. H. Kottcamp, Jr. (Consultant)

57. M. J. Mayfield (Consultant)

58. J. T. Stringer (Consultant)

EXTERNAL DISTRIBUTION

59. AIRESEARCH MANUFACTURING CO. OF CALIFORNIA, $2525 \mathrm{~W}$. 190th St. Torrance, CA 90509

J. Lohay

60. THE AMERICAN SCHACK COMPANY, INC., 9730 Rinaman Rd., Wexford, PA 15090

S. R. Meder

61. AIR PREHEATFR DIVISION OF COMBUSTION ENGINEERING, Wellsville, NY 14895

D. Figenscher

62. AMSLER-MORTON CO., Manor Building, 564 Forbes Ave., Pittsburgh, PA 15219

H. E. Metcalfe

63. BATTELLE COLUMBUS LABORATORIES, 505 King Ave., Columbus, OH 43401

C. W. Kistler, Jr.

64. BETHLEHEM STEEL, HOMER RESFARCH I_ABORATORIES, Bethlchem, PA 18016

R. Venable

65. COOR3 PORCELAIIN CÜ., GUU Ninth St., Golden, CO 80401

T. H. Nielsen 
66. DES CHAMPS LABORATORIES, INC., East Hanover, NJ 07936

N. H. Des Champs

67-68. EG\&G IDAHO, INC., P.O. Box 1625, Idaho Falls, ID 83401

A. Richardson

W. P. Jensen

69. ELECTRIC POWER RESEARCH INSTITUTE, 3412 Hillview Ave., P. O. Box 10412, Palo Alto, CA 94303

W. T. Bakker

70. ESCHER, INC., 3035 Sylvania Ave., Toledo, OH 43613

G. Barry Morse

71. GTE SYLVANIA INC., CHEMICAL AND METALLURGICAL DIV., Tuwanda, PA 18848

1. S. Cleveland

72. GRANCO EQUIPMENT CO., Grand Rapids, MI 49503

C. B. Gentry

73. HAGUE INTERNATIONAL, 3 Adams St., South Portland, MA 04106

I. W. Bjerklie

74. HOLCROFT \& CO., 12068 Market St., Livonia, MI 43150

R. Meyer

75-76. INSTITUTE OF GAS TECHNOLOGY, 3424 S. State St., IIT Center, Chicago, IL 60616

D. Larson

C. J. Marnell

77. IONICS, INC., P. O. Box 99, Bridgville, PA 15017

J.W. Seehausen

78. LOFTUS ENGINEERING CO., One Oliver Plaza, Pittshburgh, PA 15222

W. Dibartola

79. NORTON CO., One New Bond St., Worcester, MA 01606

N. Ault

80. OWENS-ILLINOIS, INC., CORPORATE TECHNOLOGY, P. O. Box 1035, Toledo, OH 43666

.H. L. McCollister 
81. ROCKETDYNE DIVISION, ROCKWELL INTERNATIONAL, 6633 Canoga Ave., Canoga Park, CA 91304

H. W. Carpenter

82. SOLAR DIVISION OF INTERNATIONAL HARVESTER, 2200 Pacific Hwy., San Diego, CA 92112

A. G. Metcalfe

83. SURFACE COMBUSTION DIVISION, MIDLAND ROSS CO., 2389 Dorr St.,

Toledo, $\mathrm{OH} 43607$

Arvind Thekdi

84. TERRATEK, UNIVERSITY RESEARCH PARK, 420 Wakara Way, Salt Lake City, UT 84108

R. Harrison

85. THERMAL TRANSFER, 1100 Rico Road, Monroeville, PA 15146

G. L. Hanson

86. DOF, FOSSLL ENERGY DIVISION, Fuel Utilization, E 178-GTN, Washington, D. C. 20545

M. Perlsweig

87. DOE, IDAHO OPERATIONS OFFICE, Idaho Falls, ID 83401

W. H. Thielbahr

88. DOE, ADVANCED CONSERVATION TECHNOLOGY, Office of Assistant Secretary,

Conservation and Solar Energy, 20 Massachusetts Ave., Rm 2220, Washington, D. C. 20585

E. Karl Bostress

89. DOE, FOSSIL ENERGY DIVISION, Office of Advanced Research and Technology, C156 GTN, Washington, D. C. 20545

\section{S. J. Dapkunas}

90-92. DOE, INDUSTRIAL PROGRAMS, Office of Assistant Secretary, Conservation and Solar

Energy, Forrestal Bldg., 1000 Independence Ave., Room 2H085, Washington, D. C. 20585
J. N. Eustis
D. G. Harvey
J. W. Osborne

93. DOE, OAK RIDGE OPERATIONS OFFICE, P. O. Box E, Oak Ridge, TN 37830

Office of Assietant Manager, Encrgy Rescarch and Devclopment

94-120. DOE, TECHNICAL INFORMATION CENTER, P. O. Box 62, Oak Ridge, TN 37830 